DOI: $10.11649 /$ abs. 2014.008

\title{
Ilga Jansone
}

Latvian Language Institute

Rìga

ilgajan@lza.lv

\section{On flora semantics in house names found in Vidzeme: materials contained in the $\mathbf{1 8 2 6}$ counting of souls in Vidzeme province}

Information contained in the counting of souls wherein are found both house names and names of individuals are an essential aspect of historical onomastics.

The first counting of souls in Vidzeme took place in 1782 and coincided with the $4^{\text {th }}$ analogous census of the provinces of Russia. Subsequently these took place at irregular intervals, the $5^{\text {th }}$, in 1795 , the $6^{\text {th }}$, in 1811 , the $7^{\text {th }}$, in 1816 , the $8^{\text {th }}$, in 1834 , the $9^{\text {th }}$, in 1850 , and the final, $10^{\text {th }}$, in 1858 .

Census of manors included persons living on private and Crown properties, as well as their constituent parts (lesser or half manors, peasant homes, taverns, mills, etc.), as well as those living in parish manors. In the earliest census, including that of 1811 only men was recorded, and even those, only partially. From 1816 onwards, all individuals resident were counted, independent of their age or gender. In the 1826 census the data for Vidzeme were not entered separately (it may be regarded as a simple copy of the census of 1816); however, this census is particularly significant as it recorded surnames for peasants in Vidzeme, i.ie. full names, given name, patronymic, surname, as well as the name of their home were noted, the latter particularly important in that it provides insight into the relationship between surnames and house names, reducing the risk of drawing spurious conclusions. 
Previously peasant families were listed with sequential numbers, each family given its own designation; this practice survived even after attribution of surnames, but in the $9^{\text {th }}$ and $10^{\text {th }}$ censuses these numbers were changed, indicating nevertheless the number assigned to the family in a previous census. The population was grouped into two broad categories, tax payers and those subject to military service (Steuer- und Rekrutenpflichtige) and those who were only taxpayers (Steuerpflichtige).

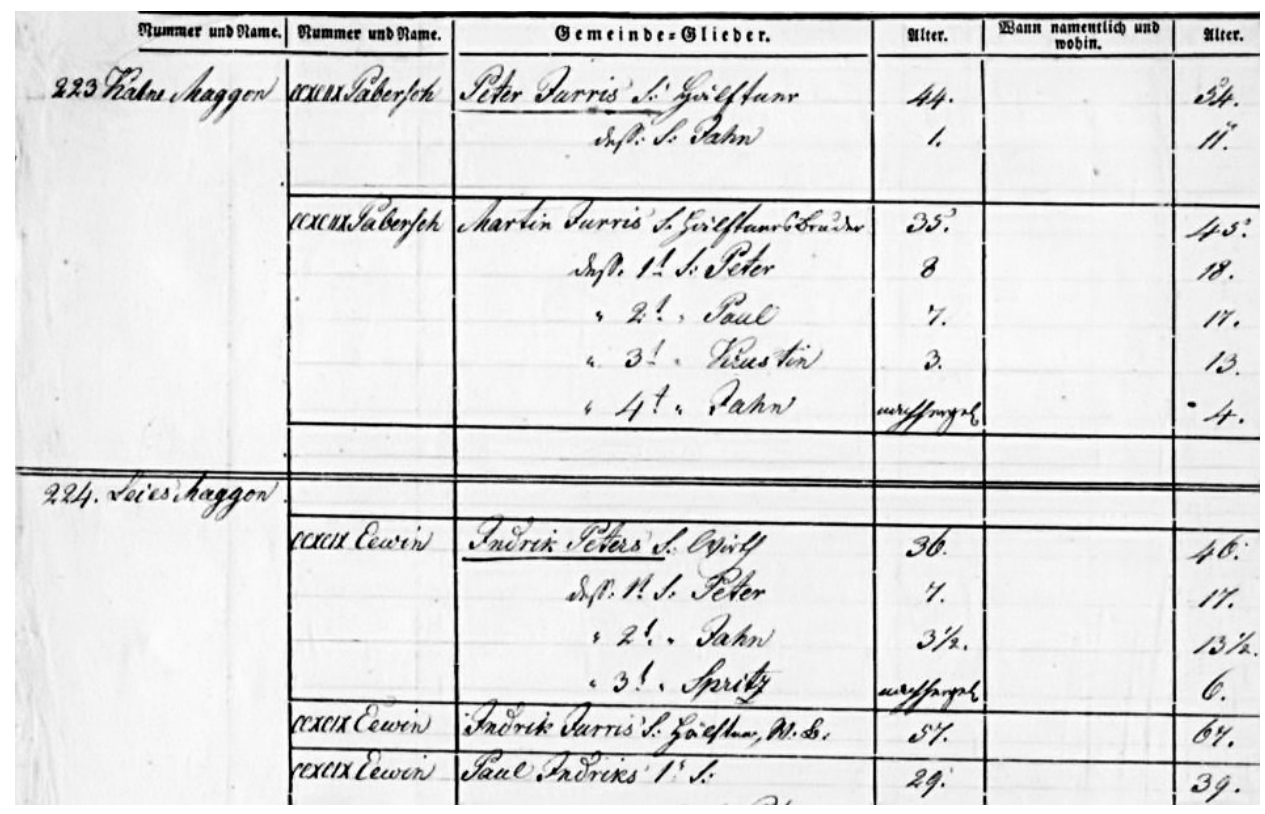

Figure 1. Part of document from the 1826 counting of souls in Vidzeme province describing the residents of Jaunpiebalga private manor (LVVA 199. foundation., 1. description, 340. 1., 109. page)

In Vidzeme various counting of souls have recorded the residents in 686 manors, several of which had been consolidated by the time of the census in 1826 and 1834 .

The number of house names entered in the 1826 counting of souls in Vidzeme province (guberna) is 14500 , including those of peasant homes that had been separated from another property whilst retaining the same name. For example, in 1826, four dwellings were recorded with the same house name Kannep ${ }^{1}$ in Jaunpiebalga Parish, and within Jaunpiebalga private manor; as well as four dwellings in the same territorial region with the name Kalne Maggon ${ }^{2}$; furthermore, four dwellings within

1 Trans. note, an archaic form of the modern Latvian term for hemp

2 Trans. note, an archaic form of the modern Latvian term for hill poppy 
Ranka private manor, located in the same parish, bear the identical name Kipplok ${ }^{3}$, and two, the name Lasdup ${ }^{4}$.

House names based on floral semantics are listed for 574 dwellings, which represent just about $4 \%$ of all house names listed for Vidzeme, providing that repeated house names are counted separately. In the case of several manors data is missing (lost) for the 1826 census, information for these manors is taken from previous and subsequent censuses.

A separate paper could be written about the orthography of names in the various censuses of ploughs and souls in Vidzeme; in many cases spelling has been determined not only by poor writing skills of those recording the facts, but also by a lack of understanding of the Latvian language, evidence for which are the presence of parallel forms for identical names, and the use of German words, for example, German nouns that describe objects, Gesinde, Hoflage, Buschwächter, Lande, Krug, Mühle, or descriptive nouns, i. e. Wirtschaft, Sohn, Frau, and, in several cases, house names are prefixed by descriptors, Alt, Neu.

One may only speak about the creation of peasant homes in Vidzeme from the $15^{\text {th }}$ century onwards. The first house names might well have been attributed at the same time; however, the only reliable information about this process dates from the first half of the $17^{\text {th }}$ century onwards. The number of peasant homes (freeholds) greatly increased in the $19^{\text {th }}$ century, with families sub-dividing and setting up separate households, as well as peasants buying out properties that previously could only be leased. Thus we may regard the early $19^{\text {th }}$ century as a time when local cultural values changes substantially, notably the setting up of single households that integrated well into the landscape. Latvian links with nature are reflected both in Latvian folk songs and in the choice of sacred sites as well as locations for dwellings.

The group of house names of floral semantic origin is not extensive; however, this group, as well as the group of house names derived from fauna, attest to the Latvian way of life at the time when dwellings acquired names.

\section{Names based on deciduous tree names}

In many instances (279 cases registered) house names were based on the names of deciduous trees found in their immediate vicinity: such names comprise $48,6 \%$ of all house names of floral semantic origin. Essentially these names are based on trees that have special symbolic meaning.

\footnotetext{
3 Trans. note, an archaic form of the modern Latvian term for garlic

4 Trans. note, an archaic form of a part synthesis of the terms for hazel tree and river
} 
The leading source of such house names is the oak-tree (in Latvian, ozols, Quercus). This phytolexeme both in common speech and in dialect forms, is seen in 67 house names, or $12 \%$ of all house names based on floral semantics, and $24 \%$ on names derived from names of deciduous trees. The lexeme, ozols, in house names is found either as the full name, (i.e., Ohsol, Ohfol, Ohfohl, Ofol), or in derivative form (i. e., Ohsolin, Ofolin, Ohfolin, Ohfoling, Ohsolnek, Ohsulin, Ohfeling), in compound names (i. e., Ofulkalln, Ohselkass) and combined names, (i. e., Kaln Ohfol, Leies Ohfol, Ohsol Krug, Ohfel Krim), as well as in combined forms (i. e., Kalne Osoling, Jaun Ofolin, Ohfolin Muifcha).

The appellative ozols is found in the first dictionaries of the Latvian language published in the $17^{\text {th }}$ and $18^{\text {th }}$ centuries $^{5}$ (compare, Ohfohls 'oak-tree, Eichbaum' in Lettus, 1638, p. 51, also in Phras. Lettica, 1638, p. 333; and, Ohfols, tas 'an oak tree, ein Eichenbaum' in Lange, 1773, p. 119); the renowned scientists of Indo-European languages Tamaz Gamkrelidze and Vjacheslav Ivanov are of the opinion that the name for oak-tree in Baltic languages (Latv. uôzuõls, Lith. áužuolas, Prussian ansonis) is of recent vintage and has replaced an older term that could have been related to the name of the god Pérkons (Гамкрелидзе \& Иванов, 1984 (2), p. 615; see also Sabaliauskas, 1990, p. 155, Kregždys, 2012, p. 34).

Following investigations of surnames by Pauls Balodis (Balodis, 2008, p. 183), including material gathered during the $20^{\text {th }}$ century, it was found that the most wide-spread Latvian surname derived from the name of trees is ozols (a total of 1242 recurrences have been found ${ }^{6}$, out of which there are 507 surnames, Ozols, and 672 surnames, Ozolinňs). The popularity of ozols as the basis for house names and surnames appears to derive from mythology and folklore, as well, as the prominent place of oak-trees in the Latvian cultural space. A detailed study of the onomastics and anthroponomy of the word, ozols, is given by Ojārs Bušs (Bušs, 2012, pp. 121-129).

The second most wide-spread floral semantic source for house names in Vidzeme is berzs (birch-tree, Betula). This phytolexeme is the basis for 50 house names, that is $8,7 \%$ out of all house names with a floral semantic basis, and $18 \%$ out of all names based on the names of deciduous trees. As noted above, the lexeme berrzs is found in house names as the full name, usual in the feminine case, (i. e., Behrfe, Behrse, Berfe, Berse), as well as in derivative form (i. e., Behrfin, Behrfin, Behrsing), joined form (i. e., Behrfahre, Berskal, Berfekaln, Behrfemnek, Behrfeleit) in composite form (i. e., Berse Millne), as well as other forms (i. e., Wetz Bersing, Jaun Berfing).

${ }^{5}$ Entries from the first dictionary of the Latvian language by Georg Mancel, Lettus and the LatvianGerman dictionary compiled by Jakob Lange who lived in Vidzeme are used for comparison purposes. Exceptionally, other dictionaries of the Latvian language dating from the $17^{\text {th }}-19^{\text {th }}$ centuries are referred to.

${ }^{6}$ Pauls Balodis based his findings from statistical analyses carried out by Velta Staltmane of approximately 20000 surnames (for 80000 individuals); seе Сталтмане, 1981. 
The appellative berrzs may also be discerned in the house name Pabehrse; alternatively, it is possible that this house name might derive from the name of a different tree, one that in modern Latvian is called parastais bèrzs (i. e. buckthorn, Rhamnus cathartica), also as parastais paberrzs. It is possible that the name of birch-trees is associated with house names that are based on the lexeme bērša or bèrža (i. e., Behrscha, Behrfche, Berfche).

The appellative, beerzs, is found in records pre-dating the first dictionaries of the Latvian language that appeared in the $17^{\text {th }}$ and $18^{\text {th }}$ centuries (compare, Båhr $\int a$ 'Bircken' in Lettus, 1638, p. 35, and also in Phras. Lettica, 1638, p. 333; as well as Behrs, tas 'die Birke' given by Lange, 1773, p. 54); the appellative has retained in all Baltic languages the archaic root ${ }^{*} \mathrm{~b}^{[\mathrm{h}]} \mathrm{erH} \hat{k}$ ' from which the Latvian nouns berrzs, berrze, the Lithuanian béržas, the Prussian berse are derived (Гамкрелидзе \& Иванов, 1984 (2), p. 619; see also Sabaliauskas, 1990, p. 39, and Kregždys, 2012, p. 14).

The wide-spread reference to this tree may be related to the extent of its presence in the Latvian landscape; this tree has lost a part of its folkloric and mythic context. T. Gamkrelidze and V. Ivanov point out that in ancient times the birch tree was one of the trees most extensively used in the natural economy, and had associations with cleanliness and virginity (Гамкрелидзе \& Иванов, 1984 (2), p. 620). P. Balodis concluded (Balodis, 2008, 181), that the appellative berrzs is the second most popular phytolexeme for surnames, and also that its diminutive form Bèrziņs is a more widely encountered surname than its analogue, the surname Ozoliňs, i. e. out of 860 surnames there are 16 occurrences of Bèrzs, and 834, of Bērziñš.

A slightly unexpected finding was that the third most widely encountered phytolexeme in Vidzeme is kärkls (sallow, Salix), that is the basis for 39 house names, or $6,8 \%$ of all house names based on floral semantics, and $14 \%$ of house names derived from names of trees. The lexeme karrkls is found in house names both in its entirety (i. e., Kahrkle, Karkle), as well as in derivative forms (i. e., Karklin, Karkliht, Kahrkling, Karklen, Aiskahrklis), combined forms (i. e., Kahrkleanz) and joined words (i. e., Wezz Karkle, Karkle Krug), and other forms (i. e., Mas Kahrklen).

In addition to the cases mentioned above, it is possible that the lexeme kārkls is the basis for house names which contain the vowel e inserted in the base name, i. e., Karkel, Kahrkel.

The appellative kārkls is found in the first dictionaries of the Latvian language dating from the $17^{\text {th }}$ and $18^{\text {th }}$ centuries (compare, Kahrklis 'Sahlweiden', in Phras. Lettica, 1638, p. 333; and, Kahrkli 'Weidenbaum', given by Lange, 1773, p. 139). It is also possible to include it in Baltic lexicon, and it can in a derivative and semantic way be correlated with similar occurrences in western and eastern Baltic languages, that is, these contain no morphological semantic parallels with other Indo-European languages, e. g. in Latv. kà̀rkls, in Lith. kar̃klas (Kregždys, 2012, p. 34; see also Sabaliauskas, 1990, p. 156). 
Is it possible that the contemporary Latvian problem of fields growing over uncontrollably (very often with sallows predominating) existed in the $19^{\text {th }}$ century or even earlier? It is also possible that the unkempt appearance of certain houses caused them to be named after this minor bush. However, occurrence of the phytolexeme $k \bar{a} r k l s$ is not all that rare as a surname (312 are recorded), and the diminutive form Kārkliņš was recorded 289 times (Balodis, 2008, p. 182).

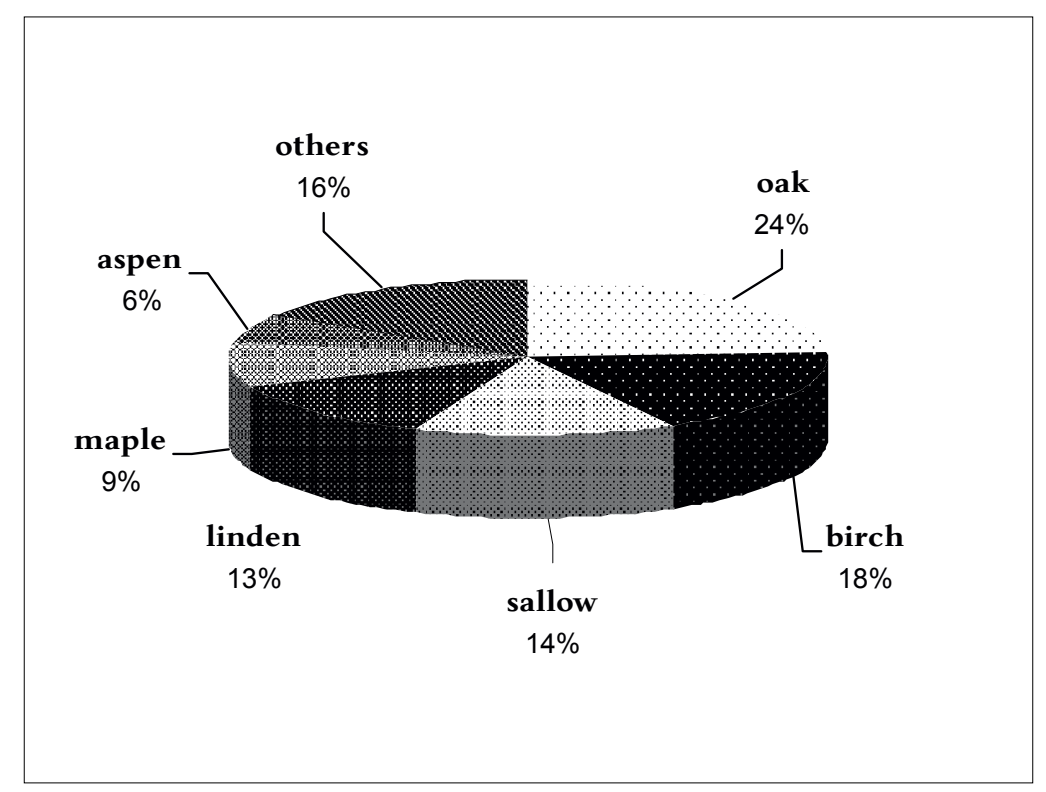

Figure 2. Names of deciduous trees in house names in Vidzeme

Only slightly fewer house names, 37 cases recorded, or 6,4\% of all house names based on floral semantics, and $13 \%$ of house names derived from names of trees, are based on the phytolexeme liepa (linden tree, Tilia), a lexeme that, as is the case for ozols, has definite mythological and folkloric meaning. The lexeme liepa is found in house names both in its entirety (i. e., Leepe, Lehpe, Lepe), and in various derivative forms (e.g., Leepin, Lehpin, Lehping, Leepan, Leepeneek, Paleep), compound forms (e.g., Leepeskalp, Leepsemnek, Leepkahje, Leepkaln, Lepfall) and combined names (e.g., Kalne Leepe, Leies Leepe, Leepe Murnek, Leepe Krug), and other forms (e.g., Kalne Leeping, Leepin Ausan, Leel Lepefal, Mas Lepefal).

This semantic group contains a number of house names containing lep-and lehp-, wherein the adjective liels (large) is found in the vocalised forms - leel and lehl.

The appellative liepa is found in the first Latvian dictionaries that date from the $17^{\text {th }}$ century (compare, Leepa 'Linde', listed by Lettus, 1638, p. 118, and Leepa 'Linden' in Phras. Lettica, 1638, p. 333); it also is part of the set of phytolexemes that both as 
derivatives and semantically correlate with Baltic and Slavic equivalents, compare, Latv. liẽpa, Lith. líepa, Prussian lipe, Russ. лuna, Polish lipa, Bulg. лuna (Sabaliauskas, 1990, p. 121; Kregždys, 2012, p. 26).

Laimute Balode (Balode, 2012) has extensively written about the onomastic relationship of, the term liepa with folklore and mythology. P. Balodis (Balodis, 2008, p. 183) concluded that the appellative liepa is the third most widely encountered phytolexeme in Latvian anthroponimy. In surnames it is most often found in its diminutive form Liepiņš with 539 instances recorded (compare, Liepa - 169 instances, thus, giving a total of 723 surnames based on the phytolexeme liepa).

Among additional house names based on names of deciduous trees the following are found in order of decreasing frequency: the lexeme klava (maple tree) - 25 instances $(4,4 \%$ of all house names based on floral semantics, or $9 \%$ of house names based on deciduous tree names); however, it must be admitted that the orthography of the time does not permit a clear separation between house names based on two homonyms, the phytolexeme klava (Acer), and the given name Klävs. For example, in the case of a house named Klaw located in Grāvesmuiža half-manor, Krimulda Parish, the head of this household is named as Klāvs (son of Ansis). It is possible that in in this particular case we have found an anthroponym. Evidently derived names (e. g., Klahwen, Klahwan) and combined names (e. g., Kalna Klahwinen, Leijes Klahwinen, Sehmul Klahwin), that are based on the root klahw- might well derive from on the given name of an individual Klāvs, and not the phytolexeme klava.

The lexeme klava is found both in its basic form in house names (i.e., Klawa, Kliawe, Klaw), and derivative forms (i. e., Klawin, Klawing, Klawan, Klawahn, Klawehn, Klawinehn), combined forms (i. e., Klawes(proge, Klawkrust) and composite forms (i. e., Klawe Taurin) and other forms (i.e., Klawais Bertul).

The appellative klava is found in the first Latvian dictionaries dating from the $17^{\text {th }}$ and $18^{\text {th }}$ centuries (compare, Kl lawa 'Löhnenholtz' found in Phras. Lettica, 1638, p. 333, with Kḷawaskohx 'Efchenbaum' listed by Lettus, 1638, p. 55; and Kḷawa, ta 'ein Lehnbaum' given by Lange, 1773, p. 139). This appellative is based on the most ancient Indo-European lexicon, with related forms found in Baltic, Slavic, Germanic and other Indo-European languages, which are associated with Indo-European terms based on the root form ${ }^{\star} k e l-$, combined with the particle, $-v$-, characteristic of Baltic languages; compare, the Latv. klavs, klava, Lith. klẽvas and the Russ. клен, Polish klon, Bulg. клен, Welsh kelyn, Old Icelandic hlynr (Sabaliauskas, 1990, pp. 40, 41; Kregždys, 2012, p. 14).

The phytolexeme klava is the basis for numerous Latvian anthroponyms: in surnames it was recorded in 415 instances, out of which the diminutive form Klaviñ was recorded 326 times (Balodis, 2008, p. 182).

Similar difficulties are encountered in identifying house names that might be derived from the term apses (aspen, Populus), which was detected in 18 instances 
$(3,1 \%$ of all house names based on floral semantics, or $6 \%$ of house names based on deciduous tree names), since in the absence of a consistent representation of diacritical marks as well as the presence of the modified ending, $e$, it is impossible to distinguish between the lexemes apse, and apsis (the latter denoting a badger).

The lexeme apse is found in house names both in its basic form (i. e., Apse, Apfe, $A b \int c h e$ ), in derivative forms (i. e., Apsiht, Apfit, Apfehn), in compound forms (i. e., Apfchekaln, Apfche(all) and in combined forms (i. e., Apfche Krug), and other forms (i. e., Kalne Apsan, Leies Apsan).

The appellative apse is found in the first Latvian dictionaries that date from the $17^{\text {th }}$ century (compare, Apfa, 'Efpen' listed in Phras. Lettica, 1638, p. 333, and the term Apfakohx 'Afpenbaum' found in Lettus, 1638, p. 23); in all Baltic languages this appellative has retained its ancient $\operatorname{root}^{*}(\mathrm{H}) \operatorname{osp}^{[\mathrm{h}]}$ - which has evolved to become the Latv. Term apse, the Lith. ápušé, Prussian abse (Гамкрелидзе \& Иванов, 1984 (2), p. 626; see also Sabaliauskas, 1990, p. 39, Kregždys, 2012, p. 14).

The lexeme apse is rather rarely found as the basis for Latvian surnames, as only 120 instances were recorded (Balodis, 2008, p. 181).

Rather few house names are based on the tree name osis (ash tree), 11 cases recorded.

The lexeme osis (Fraxinus) is found in house names both in its basic form (i. e., Ohfche, Osche), in combined forms (i. e., Ohfchup, Oschkaln, Oschkaij, Ofchbohl), and other forms (i. e., Ohfche Krug, Ohfche Pekfchan, Schnapste Osche Jurr).

The appellative osis is found in the first Latvian dictionaries dating from the $17^{\text {th }}$ and $18^{\text {th }}$ centuries (compare, Ohfcha 'Efchenbaum' listed in Phras. Lettica, 1638, p. 333; with the entry Ohfis, tas 'ein Efchenbaum' given by Lange, 1773, p. 219). This appellative is based on the most ancient Indo-European lexicon, with related forms occurring in Baltic, Slavic, Germanic Italian, Greek and other Indo-European languages, compare, the Latv. osis with Lith. úosis, Prussian woasis, Russ. я́ceнь, Polish jesion, jasień, Ancient Icelandic askr, Gr. ỏ łún, Albanian ah (Sabaliauskas, 1990, p. 44; Kregždys, 2012, p. 15).

The appellative osis as a surname has been recorded in 290 instances (Balodis, 2008, p. 183).

Very few house names in Vidzeme are entirely based on the lexeme alksnis (alder, Alnus), and only 9 occurances were recorded of alksnis, elksnis.

The lexemes alksnis, elksnis are found in house names both in basic form (i. e., Alksnis, Alkfchne), derivative forms (i. e., Daugaw Aiselksne) and combined forms (i. e., Jaun Alkfchne, Leies Alkfchne, Wetz Alkfchne, Widde Alkfchne, Alkfchne Krug, Siehle Alksne, Alkschne Mille).

The appellatives alksnis, elksnis are found in the first Latvian dictionaries dating from the $17^{\text {th }}$ and $18^{\text {th }}$ centuries (compare, Allkfchna, Ellkfchna 'Ellernbaum', listed in Phras. Lettica, 1638, p. 333, with Allckfchnakohx, Wallh., Ellckfchna, 'Ellernbaum', found in Lettus, 1638, p. 52; additionally, Alkfßchnis, tas 'Ellern', is given by Lange, 
1773, p. 13); these lexemes have, in all Baltic languages, retained the ancient root *eliso- $/ /{ }^{*}$ aliso-, on the basis of which there developed the following terms, the Latv. alksnis, elksnis ${ }^{7}$, the Lith. alksnis, and Prussian ${ }^{\star}$ alskande (Гамкрелидзе \& Иванов, 1984 (2), p. 635; see also, Sabaliauskas, 1990, p. 38, Kregždys, 2012, pp. 16, 17).

The lexemes alksnis, elksnis are the basis for 179 recorded surnames (Balodis, 2008, p. 181).

A number of houses are named lazdas (hazel-tree, Corylus), with 10 instances recorded.

The lexeme lazda is found in house names both in its basic form (i. e., Lasde), and in derivative forms (i. e., Lasding), in combined forms (i. e., Lasdup) and joined forms (i. e., Lasdes Jahn, Lasdes Mickel). A number of house names (e. g., Lesdin, Lesding) are derived from the dialect form lezda; these house names are found distributed throughout Trikāta and Palsmane Parish, congruent with the spatial distribution of the lexeme lezda (see ME II, p. 455).

The appellative lazda is found in the first Latvian dictionaries dating from the $17^{\text {th }}$ and $18^{\text {th }}$ centuries (compare, Lafdakohx 'Hafelftaude' listed in Phras. Lettica, 1638, p. 333, with, Laßdakohx 'Hafelftaude', given by Lettus, 1638, p. 85). Baltic languages (together with Albanian, Serbian and Croatian) are part of that group of languages for which the term for hazel-tree (Corylus) differs from that for hazel nuts (seе Гамкрелидзе \& Иванов, 1984 (2), p. 637 1 ). A. Sabaliauskas and R. Kregždys attribute the term for hazel-tree to be part of an archaic Indo-European lexicon, compare, the Latv. lazda, Lith. lazdà, Prussian laxde, Polish łoza, Albanian lajthi, lakthi (Sabaliauskas, 1990, p. 41; Kregždys, 2012, p. 14).

The appellative lazda (and variants thereof) is related to 360 recorded Latvian surnames (Balodis, 2008, p. 183).

Only 5 house names were recorded based on the phytolexeme vitols (willow, Salix).

The lexeme vitols is found both in its basic form in house names (i. e., Wihtol, Witol), as well as in combined names (i. e., Jaun Witol). In two distant Manors in Vidzeme (located in Krimulda and Burtnieku parishes) the dialect form vituls is used as the house name (Wihtul); this term has been described in a dictionary compiled by Kārlis Mülenbach and Jānis Endzelīns, as to be encountered in Vecpiebalga and Rūjiena (sal. ME IV, p. 648).

The appellative vitols is found in the first Latvian dictionaries dating from the $17^{\text {th }}$ and $18^{\text {th }}$ centuries (compare, Wietols 'Weidenbaum', listed in Phras. Lettica, 1638, p. 333, with, Wietohls 'Weidenbaum', recorded in Lettus, 1638, p. 204; and, Wihtals, wihtols 'eine Art Weiden', given by Lange, 1773, p. 391).

\footnotetext{
7 T. Gamkrelidze un V. Ivanovs considered only Lithuanian and Prussian terms.
} 
According to T. Gamkrelidze and V. Ivanov, many Indo-European languages have retained the ancient root for willow-tree ${ }^{*^{\prime}}(\mathrm{e}) \mathrm{lik}^{[\mathrm{h}]}$; however, it is the case that in several languages, including Latvian and Lithuanian, the ancient term has been supplanted by a descriptive noun, with meaning 'a tree with branches suitable for weaving' and derives from the Indo-European *ueu-, 'to weave' extended by the suffix $*_{-}$th] $_{\text {- }}$ (Гамкрелидзе \& Иванов, 1984 (2), p. 637 $)$.

The appellative vittols occurs in 391 Latvian surnames (Balodis, 2008, p. 184)

In a limited number of cases ( 3 instances recorded) house names are associated with the appellative ieva (bird cherry).

The lexeme ieva is found in house names both in derivative form (i. e., Eewan, Eewin), as well as in combined form (e. g., Ehwulietz). The house name Ievulicis shows a definite linguistic link to this tree, in that it refers to the usual area where these (Padus) grow, i. e. along shores of rivers; a number of other house names may be based on the anthroponym Ieva.

The appellative ieva is found in the first Latvian dictionaries dating from the $17^{\text {th }}$ and $18^{\text {th }}$ centuries (compare, Eewa 'Faulbaum', listed by Phras. Lettica, 1638, p. 333, with Ewa/Eewaskohx 'Faulbaum', recorded in Lettus, 1638, p. 58; as well as with Eewa, $t a$ 'ein Faulbeer Baum', given by Lange, 1773, p. 108).

The lexeme ieva has retained the ancient Indo-European root *ei-/*oi-, with the suffix ${ }^{*}$-uno-, appended. T. Gamkrelidze and V. Ivanov indicate that derivatives of this root usually denote yew trees (Taxus), (notee also the Prussian term, iuwis); however, in several languages the ancient Indo-European term has been used to describe other flora, including bird-cherries Padus (Latv. iẽva, Lith. ievà) (Гамкрелидзе \& Иванов, 1984 (2), p. 629).

The phytolexeme ieva is found to occur rather infrequently in Latvian surnames, only 50 instances being recorded (Balodis, 2008, p. 182).

In a few house names ( 3 cases recorded) the term for pussy willow (Salix caprea) may be discerned. In house names the lexeme puppols is only found in its basic form (e. g., Puhpol, Pupohl, Pupul) with variations on the suffix.

The phytolexeme puppols is found in the first Latvian dictionaries dating from the $17^{\text {th }}$ and $18^{\text {th }}$ centuries (compare, Pupulis 'Palmbaum', listed in Phras. Lettica, 1638, p. 334, with Pupulo=kohx 'Palmbaum', listed by Lettus 1638, p. 135; as well as with Puhpuli 'Palmen', given by Lange, 1773, p. 242), the lattter offering the explanation that this term might be taken from the Bible, i. e. Palm Sunday = Püpolsvètdiena, 'der Palmsonntag'.

In Latvia, terms for this tree and its flower are based on the verb paupt (ME III, p. 448), the explanation for the latter based on the unusual term for its inflorescence.

The extent to which the phytolexeme puppols is found in Latvian anthroponomy is not mentioned by P. Balodis in his analyses.

Only a single house name was recorded that might derive from the phytolexeme viksna (elm, Ulmus), and that is in its basic form (Wieksne). 
The appellative, $v i k s n a$, is found in several $18^{\text {th }}$ century Latvian dictionaries in the form wieksne (e. g. Wihkfnes, tahs 'Röftern', given by Lange, 1773, p. 390).

T. Gamkrelidze and V. Ivanov, basing their assessment on a reconstruction due to Julius Pokornii, assert that a very old term Ulmus is found in Baltic, Slavic, Germanic languages, in Albanian and in Iranian; this term can be discerned from the roots *uei k'-, *uink'- (Гамкрелидзе \& Иванов, 1984 (2), p. 634); compare, the Latv. vîksna, Lith. vinkšnà, Prussian *vinksnā, Russ. вяз, Albanian vidh (Sabaliauskas, 1990, p. 44; Kregždys, 2012, p. 15).

The phytolexeme viksna occurs infrequently in Latvian surnames, with a total of 101 instances recorded (Balodis, 2008, pp. 181, 182).

A single house name can be associated with the tree name pìlädzis (rowan-tree, Sorbus), in terms of its dialect form pìlags. The phytolexeme pìlādzis is found in several $18^{\text {th }}$ century dictionaries of the Latvian language (see Pihlahdfchi 'Pielbeern', given by Lange, 1773, p. 234); its dialect form pilags, was recorded along the Vidzeme sea-shore, including Umurga (see $6^{\text {th }}$ map, LVDA), where the house name Pilag was recorded.

Jānis Endzelīns observed that the Latv. pìlādzis, and its dialect variant pìlāgs has been adopted from the Liv language pilag (ME III, p. 231, see also the entry, $p^{\prime}{ }^{\prime} l \hat{g} G$ in Kettunen, 1938, p. 297).

The appellative pillädzis, together with its variants was noted to occur in only 13 Latvian surnames (Balodis, 2008, p. 184).

Various terms denoting deciduous trees constitute the basis for about one-half of all house names derived from floral semantics. Their rather frequent appearance is associated with linguistic and extra-linguistic factors. The most widely used lexemes are those describing oak-trees, birch trees and linden trees (see Fig. 2). These trees are not only the most commonly found trees in the Latvian landscape, but also have a special place in Latvian folklore and mythology, the oak tree a symbol of boys, the linden tree, a girl (e. g. An oak tree grew, a linden tree grew/ they looked at one another/ As you saw for yourself/ The oak tree proposed to the linden tree ${ }^{8}$ ). An exception one must remark the wide-spread distribution of names derived from the term for sallows, testament to its practical use in weaving, its negative folklore connotation and instrusive presence in the landscape notwithstanding.

A similar picture obtains for the distribution in Northern Kurzeme of place names based on phytolexemes. Dzintra Hirša in her study of place names in Sarkanmuiža shows that place names in this region, based on names of deciduous trees, most often derive from bèrzs, liepa, and ozols. The place taken by the lexeme $k \bar{a} r k l s$, taken by the name for a different tree alksnis (Hirša, 1990, pp. 102-148).

\footnotetext{
${ }^{8}$ In the original, Ozols auga, liepa auga,/ Viens otrâ vērdamies./ Kà jūs paši redzejat,/ Ozols liepu bildinaja. BW 12198
} 


\section{Names derived from terms for conifers}

Without being as widely encountered as the names derived from terms for deciduous trees, house names based on names for conifers are found (in all 35 instances were recorded, or $6,1 \%$ of all house names based on floral semantics), out of which the most popular is the appellative egle (recorded 14 times).

The lexeme, egle (spruce tree, Picea) is found in its basic form in house names (i. e., Egle, Egles), and in derivative forms (i. e., Egliht, Egglit, Eglain, Eglein) and combined words (i. e., Jaun Egle, K. Egle, L. Egle), and other combined forms (i. e., Kalne Egliht, Leijes Egliht).

The appellative, egle, is found in the first Latvian dictionaries dating from the $17^{\text {th }}$ and $18^{\text {th }}$ centuries (compare, Eggle 'Fichtenbaum', listed in Phras. Lettica, 1638, p. 333; with, Egle, ta, 'Graenbaum al. Tannen', given by Lange, 1773, p. 109); this appellative, found in all Baltic languages, has retained the old root. *ed[h]lo-, whose original meaning might have been, conifer, from which there developed the Latv. egle, the Lith. églè, Prussian addle (Гамкрелидзе \& Иванов, 1984 (2), p. 619). A. Sabaliauskas and R. Kregždys attribute this term to a common Baltic and Slavic lexicon, as parallel forms are found in both of these language groups (Sabaliauskas, 1990, pp. 120, 121; Kregždys, 2012, p. 26).

The lexeme egle may be discerned in 333 Latvian surnames (Balodis, 2008, p. 181)

Fewer house names have been recorded (11 occurrences) based on the term, paeglis (Juniperus), and variants thereof. The lexeme paeglis is found in its basic form in house names (i. e., Paegle, Paegli), as well as in combined form (i. e., Wezz Paegle). The house name Paigel, recorded in Diklı Parish is based on a variant form paigel. The Dialectal Atlas of Latvian Vocabulary (Latviešu valodas dialektu atlants) indicates in data collected on lexica that the forms paigle and paiglis have been registered over a wide area of North-western Vidzeme (see the $9^{\text {th }}$ map, LVDA). The name Padegge krug (see also the surname Padegs), of a tavern located in Aizkraukles Parish may be associated with the term for juniper. The first element of this combined form may be a contaminated version of standard terms paeglis and kadikis for Juniperus communis.

The appellative paeglis is found in the first Latvian dictionaries dating from the $17^{\text {th }}$ and $18^{\text {th }}$ centuries (compare, $P a=$ eggless 'Wacholderbaum', found in Phras. Lettica 1638, 333, and $P a=$ eggless 'Wacholder', found in Lettus, 1638, p. 98; with, Paehgle 'Wacholder', given by Lange, 1773, p. 221).

Dialect synonyms for the lexeme paeglis may be discerned in individual cases of house names

The dialect lexeme kadaks is associated with several house names recorded in the parishes of Salaca and Limbaži. The lexeme kadaks is found in its basic form in 
house names (i. e., Kaddak), as well as in combined forms (i. e., Jaun Kaddak, Wezz Kaddack, Mesche Kaddack, Uppes Kaddack).

Based on lexical data given in the Dialectal Atlas of Latvian Vocabulary (Latviešu valodas dialektu atlants) and the dictionary compiles by Kārlis Mülenbach and Jānis Endzelīns (Latviešu valodas vārdnīca) ther terms kadaks and kadags are found in Lower Kurzeme and also in Naukšeni, the latter close to the border with Estonia (see the $9^{\text {th }}$ map, LVDA, also, ME II, p. 131). Considering these lexemes to denote the same tree as does kadegss, J. Endzelinns has related them to the Lithuanian kadagỹs, and the Old Prus-

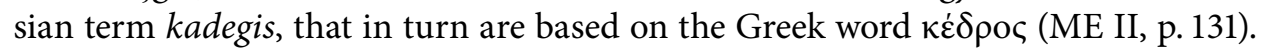
The authors of the lexical chapter of the Dialectal Atlas of Latvian Vocabulary also give as equivalent the meaning of dialect forms found in Naukšēni and Rucava.

It is more credible that the term kadaks, recorded in Naukšenni and the terms kaddak, kaddack, recorded in the parishes of Salaca and Limbaži, used as the basis for house names, appear to be related to the Estonian term kadakas, 'Wacholder (Juniperus communis L.)' (Wiedemann, 1973, p. 176), and the Liv term, kadàgi, wacholdern, aus wacholderholz (Kettunen, 1938, p. 100). The analogous lexeme (kadagi, 'Wacholder', Salis-Livisches, 2009, p. 75) has been included in the dictionary compiled by Eberhard Winkler and Karl Pajusalu. House names recorded as often encountered during the first half of the $19^{\text {th }}$ century based on Fino-Ugric terms as compared to fewer occurrences later may be explained by the progressive disappearance of this linguistic sub-stratum and ad-stratum.

Both synonyms for the tree Juniperus are found in Latvian surnames: kadikis - 22 instances, and paeglis -129 instances recorded (Balodis, 2008, p. 182).

The smallest group of house names found in Vidzeme that based on names of conifers refer to, priede (pine-tree, Pinus), of which 10 instances were recorded.

The lexeme, priede, is found both in its basic form in house names (i. e., Preede), as well as in derivative forms (i. e., Preediht) and word combinations (i. e., Kalne Preede, Leyes Preede, Preedes Inken). In individual instances house names are based on other derived forms of the lexeme priede (i. e., Predul); however, derivative forms containing the particle, -ul-, have a different meaning, namely, prieduls denotes 'pine forest, stand of pines' (ref., Preeduls, 'ein Dannen Bufch', listed in Phras. Lettica, 1638, p. 333).

The appellative priede is found in the first Latvian dictionaries dating from the $17^{\text {th }}$ and $18^{\text {th }}$ centuries (compare, Preeda 'Eine Danne', listed in Phras. Lettica, 1638, p. 333, and preeda/Preedas =kohx 'Tannenbaum', found in Lettus, 1638, p. 181; with Preede, $t a$ 'eine Tanne', given by Lange, 1773, p. 240). The German explanation of this term actually refers to spruce trees (Picea). J. Endzelins has shown that this term is based on a metastasis of the term ${ }^{\star}$ piedre (ME III, p. 392).

The phytolexeme priede has been noted to occur in 308 Latvian surnames (Balodis, 2008, p. 184). 
Place names based on the lexemes egle and priede have also been recorded in Sarkanmuiža. House names have been found in Northern Kurzeme based on names of conifers such as īve (yew tree, Taxus baccata) and èrcis (Juniperum communis) (Hirša, 1990, pp. 102-148).

\section{Names of decorative trees and bushes}

It is possible that a number of houses acquired early in the $19^{\text {th }}$ century names derived from the names of exotic flora (10 such instances have been recorded, or 1,8\% of house names derived from floral semantics). Although it seems barely credible it appears that 7 house names are based on the phytolexeme tüja (Thuja).

All of these house names are composites (Strupp Thujes, Garr Thujes, Jaun Thujes, Wetz Thujes, Tuhjas Melfup), or combined words (Latwan Tuhjan, Andre Tuhjan), and are recorded only for houses in Ledmane private manor, Lielvārdes Parish, and Bučauskas private manor, Cesvaines Parish, as well as in Alūksne castle manor.

In assessing house names based on flora not commonly found in the landscape of Latvia, it is necessary to consider other reasons for the use of such terms, in particular as in common speech the usual term is 'tree of life' ( $d z \bar{i}$ ïbaskoks) for Thuja occidentalis. One reason for the appearance of this appellative may be found in the name of Tüja manor in Liepupe Parish. In these cases the house names have used the lexeme, not deriving from floral semantics, but from names of fauna. This explanation is reasonable given that the name of the Manor House in German being, Taubenhof (German Taube 'pigeon, balodis', $H o f$ 'manor, muiža'), and the Latvian term for pigeon $d \bar{u} j a$, wherein the $t: d$ sound change night have occurred from the German term Taube. The authors of Baltisches historisches Ortslexikon advanced this hypothesis (see Ortslexikon II, p. 637). However, the name in German Kragenhof, located in Alūksne Parish whose Latvian name is Tüjas muiža, does not help in our understanding for the origin of Tüja in this context. However, the Latvian name is associated with the word for pigeon (dūja) and the von Taube family owned this Manor from 1631 to 1791 (see Ortslexikon II, p. 298). It is not possible to rule out the possibility that the origin of these 7 house names is the analogous term in German, i.e., Thuja.

The house names Pallmen and Palmen Murjahn might derive from the term palma which denotes a tree exotic in the Latvian context.

The morphological nature of the terms Pallmen and Palmen depends on the origin of these terms. If we associate house names with the term palma, they ought to be considered as derivatives.

It is possible that house names recorded in manors located in Skujene and Valmiera parish derive their names from another plant considerably more familiar in Latvia. If we examine Latvian language dictionaries from the $17^{\text {th }}$ and $18^{\text {th }}$ centuries, we discover that the meaning of the name pupols in German is Palmen, but the 
meaning of the Latvian name for the Sunday before Easter puppolsvētdiena is given in German, as Palmsonntag (compare, Pupulis 'Palmbaum', listed in Phras. Lettica 1638, 334, and Pupulo=kohx 'Palmbaum', in Lettus, 1638, p. 135; with Puhpuli 'Palmen', given in Lange, 1773, p. 242, and puhpuḷi 'Palmen', as well as, puhpuḷ fwehdeena 'Palmfonntag', is given by Stender, 1789, p. 448).

The first entries for palm trees only appear in the second-half of the $19^{\text {th }}$ century in the dictionary compiled by Karl Kristian Ulmann: palma-kohks 'Palme', in Ulmann, 1872, p. 187 and a wide-ranging explanation for the meaning of puhpoli, i. e., 'Weidenkätzchen, Zweige mit Weidenkätzchen, fogenannte Palmen, die am Palmfonntage (puhpuḷu fwehdeenâ) zu Schlägen, mit denen man die Langfchläfer weckt, und zur Zierde dienen', see Ulmann, 1872, p. 213.

This last assumption appears to be the more plausible one as house names derived from the phytolexeme puppols have only been found to occure in Vidzeme.

The house name Zerring Lihz / Zerrin Lihz might be based on the name cerini (lilacs) nosaukums; however, this is implausible as there are no entries for Syringa vulgaris, the modern Latvian term being cerini, in any Latvian dictionary including that of Gotfried Friedrich Stender that appeared at the end of the $18^{\text {th }}$ century; under the entries for Hollunder, Fleeder several ekvivalents are given, i. e. 'pluhfchu kohks, pluhtu kohks, pleederu kruhms, oder kohks', see Stender, 1789, p. 335. Of the Latvian terms referred to the first two may be associated with the bush Sambucus, whereas the last, pliederu koks vai krüms, refers to the bush, Syringa; however, this hypothesis is contradicted by the entry found in the Latvian-German dictionary compiled in 1872 by K. K. Ulmann, wherein the entry pleederi, pleederes associates these terms with the German 'Flieder, Holunder', and the Latin Sambucus nigra, see Ulmann, 1872, p. 205. If we assume that the the German terms Flieder and Holunder, refer to both plants, whereas the Latin term refers to the black version of this bush, i. e. melnais plūškoks. However, in the 1880 edition of this dictionary the German-Latvian part contains an entry referring to cerini: i. e. Holunder, Holunderbaum, is translated as pleederu kohks, pluhfchu kohks, zirenu kohks, see Ulmann, 1880, p. 413.

If one were to associate these three terms as sources for house names as describing exotic flora, then the most likely source would be articles read or stories recounted, or these plants being cultivated in near-by manors.

\section{Names of fruit trees and bushes}

House names based on names of fruit trees and bushes are only occasionally found in Vidzeme, with 8 recorded instances, or 1,4\% of all house names based on floral semantics. In the case of 7 house names are based on the name of the most widely encountered type of apple tree àbele (Malus). 
The lexeme abele (apple tree) is found in house names in basic form (i. e., Abel, Ahbel), in composite form (i.e., Ahbelskaln, Abelkuhran) and combined form (i. e., Abel Giggurt).

The appellatives àbola koks and ābele are found in the first dictionaries of the Latvian language dating from the $17^{\text {th }}$ and $18^{\text {th }}$ centuries (compare, Ahbola $=k o h x$ 'Apffelbaum', listed in Phras. Lettica, 1638, p. 324, and Abohlakohx 'Apffelbaum', in Lettus, 1638, p. 22; with Ahbele, ta 'der Apfelbaum', given by Lange, 1773, p. 4). The lexeme äbele is part of the most ancient Indo-European lexicon, it is based on roots (from different Indo-European dialects): *ăblu-, *ăb(a)lo- and *aplu-, *ap(a)la-, from which derive the Prussian woble 'ābols' (*ābl-), wobalne 'ābele' ( $\left.{ }^{\star a} b o l n-\right)$, the Lith. óbuolas, óbalas, and the Latv. äbele (Гамкрелидзе \& Иванов, 1984 (2), p. 637; see also Sabaliauskas, 1990, pp. 41, 42; Kregždys, 2012, p. 15).

It is most likely that all of these house names are based on the term for the fruit trees and not on the Biblical Abel.

Among surnames the phytolexeme, ābele, has been recorded only in 147 cases (Balodis, 2008, p. 181).

Only a single house name Uppen located within Umurga Parish, may be associated with the name for the fruit bearing bush upene (black-currant, see, uppenes 'Bocksbeern', as given in Lange, 1773, p. 363).

It appears that these bushes upenes (Ribes nigrum L.), were not widely distributed throughout Latvia; however, in 1826 a surname derived from the dialect term for this bush, Uppenafch, was recorded in Ērgeme Manor, Ērǵeme Parish.

One cannot rule out the possibility that the house name found in Umurga Parish may be a direct derivate from the noun upe (river).

\section{Names of cereals}

The next sub-group of house names based on floral semantics comprises those based on names for cereals. This is one of the most widely occurring floral semantics sub-groups and contains 58 entries, or 10,1\% out of all house names based on floral semantics.

The most popular such house names, 22 cases recorded, derive from the phytolexeme auzas (oats, Avena).

The lexeme auza is found in house names both in its basic form (i. e., Aufe), in derivative forms (i. e., Aufin, Ausing, Ausfing, Ausan, Aufen), in composite forms (i. e., Lehl Aus), in combined forms (i. e., Jaun Aufing, Wetz Aufing, Ausing Rikandi, Aufai Klahwen). It is impossible to rule out the possibility that the house name Lehl Aus may refer to the physiognomy of a person (possibly large ear) and, thus, is part of the different semantic group (based on individual appearance). 
The appellative auza is found in the first dictionaries of the Latvian language dating from the $17^{\text {th }}$ and $18^{\text {th }}$ centuries (compare, Aufas 'Habern', listed in Phras. Lettica, 1638, p. 327, and Lettus, 1638, p. 82; with Aufas tahs, 'der Haber', given by Lange, 1773 , p. 43). T. Gamkrelidze and V. Ivanov have shown that oats are chiefly grown in Europe, and this cereal has been harvested since the Iron age (approx. 500 AD). The term for oats dates from this period and is similar in various old Indo-European dialects in Europe i. e., Latin auēna, Lith. avižà, Latv. auza, Prussian wyse, Old Russ. овьсъ, Russ. овес (Гамкрелидзе \& Иванов, 1984 (2), p. 659; see also Sabaliauskas, 1990, p. 38; Kregždys, 2012, p. 14).

The phytolexeme auza has been noted to occur in 173 Latvian surnames (Balodis, 2008, p. 187).

Numerous house names (19 instances recorded) are based on the name of the cereal rudzi (rye, Secale).

The lexeme rudzis is found in house names in the form of derivatives (i. e., Rudsit, $R u d f i t, R u d f i h t$ ), joined forms (i. e., Rudfikrug) and in combined form (i. e., Lehl Aus), as well as other composite forms (i. e., Kalne Rudfiht, Leies Rudfiht, Iwann Rudfit, Jurr Rudfit, Leel Rudfgail, Mas Rudfgail). The meaning of the appellative rudzgailis is unclear. It is possible that the term refers to another bird laukirbe (Perdix perdix L.), that in several languages bears a name that has elements of a rooster (gailis), (i. e, in German, Rebhuhn, in Estonian nurmkana).

A number of other house names may be based upon the term for rye (Rugge, Ruggel) where the usual $g$ : $d z$ sound change has not occurred.

The appellative rudzi is found in the first dictionaries of the Latvian language dating from the $17^{\text {th }}$ and $18^{\text {th }}$ centuries (compare, Rudfi 'Roggen', listed in Phras. Lettica, 1638, p. 327, and Ruddfi 'Rocken', in Lettus, 1638, p. 145; with Rudfi, tee 'der Roggen', given by Lange, 1773, p. 253). Rye was first cultivated in Europe during the Bronze age, and its name derives from the root, * ${ }_{x} \operatorname{urug}[\mathrm{h}]$ io-, and is found only in Ancient Indo-European dialects in Europe, i. e., Old Icelandic rugr, Old English ryge, Old High German rokko; Lith. rugỹs, Latv. rudzis, Old Russ. prжb, Russ. poжb, Old Pol. reż (Гамкрелидзе \& Иванов, 1984 (2), pp. 658, 659; see also Sabaliauskas, 1990, p. 43; Kregždys, 2012, p. 15).

The phytolexeme rudzi as the basis for Latvian surnames has been recorded to occur slightly more often than the term from oats, i. e. 205 cases have been recorded (Balodis, 2008, p. 189).

Even fewer house names have been recorded in Vidzeme (11 cases recorded) based on the lexeme mieži (barley, Hordeum). The phytolexeme miezis is found in house names in basic form (i. e., Meefe), in derivative form (i. e., Meefiht, Meefit, Mehfit, Mesfit, Mefit, Meefiet, Mehsin), and as combined words (i. e., Meefch Andreew).

The appellative miež $i$ is found in the first dictionaries of the Latvian language dating from the $17^{\text {th }}$ and $18^{\text {th }}$ centuries (compare, Meefchi 'Gerften' Phras. Lettica, 1638, 
p. 327; Lettus, 1638, p. 74; Meefchi tee 'Gerften’ Lange, 1773, p. 188). Barley was one of the first cultivated cereals for which records exist dating from the $10^{\text {th }}$ millennium BC. In Europe barley was cultivated in the late Neolithic era, but during the bronze age it became the principal cultivated cereal (Гамкрелидзе \& Иванов, 1984 (2), pp. 658, 659). The wide-spread nature of this cereal notwithstanding, we know of no archaic term for barley in the Baltic languages. A. Sabaliauskas has shown that the Latv. miezis, Lith. míežis, Prussian moasis is associated with the Iranian verb maiz'to sow' (Sabaliauskas, 1990, p. 157; see also Kregždys, 2012, p. 34).

The phytolexeme mieži can only be discerned in 73 Latvian surnames (Balodis, 2008, p. 188).

No house names have been found in Vidzeme based on the cereal name kvieši (wheat, Triticum), although this cereal, according to archaeologist Jānis Graudonis (Graudonis, 1989, pp. 72-73), was cultivated along the lower reaches of the Daugava during the late Bronze age (1000.-500. BC).

House names in Vidzeme based on cereal names include 6 instances of names based on the phytolexeme griki (buckwheat, Fagopyrum).

The lexeme griki is largely found in its basic form in house names (i. e., Gricke, Grikke, Grükke). In several instances it is not possible to distinguish whether the house name is based on the German form, Gricken, or on a derived form.

The appellative griki is found in the first dictionaries of the Latvian language dating from the $17^{\text {th }}$ and $18^{\text {th }}$ centuries (compare, Ghricki 'Gricken'; listed in Phras. Lettica, 1638, p. 327; with Grikki, tee 'Buchweitzen', given by Lange, 1773, p. 124). The term for buckwheat in Baltic languages (the Latv. grikis, the Lith. grikis) is a loan word (Sabaliauskas, 1990, p. 238).

As is the case for house names in Vidzeme, relatively few Latvian surnames based on grikis or variations thereof, in that 76 instances have been recorded (Balodis, 2008, pp. 187-188).

\section{Names of legumes}

House names have been found based on terms for 6 legumes, which represents $1 \%$ of all house names based on floral semantics. A number of legume varieties were found on the territory of Latvia from ancient times. For example bean seeds have been found in late-Bronze age dwellings along the lower reaches of the Daugava (Graudonis, 1989, pp. 72-73); however, information about their cultivation dates from the $5^{\text {th }}$ century. (Rasiņš \& Tauriņa, 1983). Thus legumes were sufficiently widespread long ago that their names might be the basis for house names.

There is no question that house names based on the lexeme zirn, ( 3 instances). 
The lexeme zirnis is found in house names in derivative forms (i.e., Sirniht) and in combined forms (i. e., Jaun Sirne, Wetz Sirne).

The appellative zirnis (pea, Pisum) is found in the first dictionaries of the Latvian language dating from the $17^{\text {th }}$ and $18^{\text {th }}$ centuries (compare, Sirrn, $i$ 'Erbfen', listed in Phras. Lettica, 1638, p. 327, and Sirrni 'Erbs', in Lettus, 1638, p. 54; with Sirni, tee 'die Erbfen', given by Lange, 1773, p. 299). A. Sabaliauskas and R. Kregždys consider that the Latv. zirnis, Lith. žirnis, Prussian syrne derives from the oldest Indo-European lexicon (Sabaliauskas, 1990, pp. 44-45; Kregždys, 2012, p. 15).

In compilations of Latvian surnames the lexeme zirnis appears in 44 instances (Balodis 2008, p. 189).

Formally only 3 house names have been recorded based on the phytolexeme pupa (bean, Vicia faba). The lexeme pupa is only found in its basic form in house names (i. e., Puppe). The house names Puppai, and Puppai Klahwen found in two distant manors in Vidzeme are based on the semantically differen lexeme pupājs, that either refers to a field of beans or bean stalks.

The noun рира is found in the first historic dictionaries of the Latvian language dating from the $17^{\text {th }}$ and $18^{\text {th }}$ centuries (compare, Puppi 'Bohnen', listed in Phras. Lettica, 1638, p. 327, and Puppa 'Bohn', in Lettus, 1638, p. 38; with Puppas, tahs 'Bohnen', given by Lange, 1773, p. 243). The Latv. pupa, Lith. pupà, Prussian ${ }^{*} p u p a$ (discernible in place names such as, Pupkaym, Pupayn, Pupekaymen) is part of the lexicon of Baltic languages but common only to the eastern and western branches of this family (Sabaliauskas, 1990, p. 158; Kregždys, 2012, p. 34).

The appellative pupa is not found in many Latvian surnames, with only 13 instances recorded (Balodis 2008, p. 189).

\section{Names of vegetables}

Names of common vegetables are the basis for a considerable number of house names. i. e. 53 instances recorded, representing 9,2\% of all house names derived from floral semantics. The greatest individual number of such names (12 instances) refers to the vegetable grown by all households, namely, rutks (radish), also ruks, ruduks.

The lexeme, rutks, (Raphanus sativus), is found in house names both in its basic form (i. e., Rutka, Rutke, Ruttke), and in combined form (i. e., Rutkast, Rutkaft), as well as joined with given names (i. e., Rutke Jaecob, Rutke Jurre, Rutke Marting).

The appellative, rutks, is found in the first dictionaries of the Latvian language dating from the $17^{\text {th }}$ and $18^{\text {th }}$ centuries (compare, Ruttkis, Ruttka, 'Rettich', listed in Lettus, 1638, p. 142, and, Ruttki, 'Rettisch', in Phras. Lettica, 1638, p. 330; with, Rutki, 'Rettig', leeli Rutki, 'Meerrettig', given by Lange, 1773, p. 256). The term rutks is a loan word in Latvian (also in Lithuanian); however, opinions differ as to the source. 
The most widely held view is that the name for Raphanus originates with the Latin term rädix (acc. sing. rādīc-em) 'root'. The Germanic term ${ }^{\star}$ rẩdik, may have descended from the Latin, with the consonant, $c$ transformed into the consonant, $k$ preceding the vowel $e$. The German form redik was then adopted by Slavic languages in the form rbdoky. In the Slavic language Belarussian this term was transformed into rodokr, and became the source for the Latvian term, ${ }^{*}$ rudikas, or in shortened form, rutks. According to another version, Latvians borrowed the name for Raphanus from the Old Belarussian term rodok, as ${ }^{*}$ ridiks. Further changes in this term were influenced by the Latvian adjective ruds for reddish colours (see ME III, p. 565; Smoczyński, 2007, pp. 513, 514; LEV II, p. 140; Sehwers, 1953, pp. 298, 299; Sabaliauskas, 1990, p. 241).

The lexeme rutks in dialect form ruks (with spelling variations ruck, ruke, rukke), is the basis for house names throughout North-western Vidzeme and Central Vidzeme; however, it is only occasionally found in other parts of Vidzeme (see the answers to question 417 in the LVDA survey).

The dialect name ruks is found in basic form (i. e., Ruke, Rukke), as well as in derivative forms (i. e., Rukkel) and combined names (i. e., Leel Ruck, Mafs Ruck).

The lexeme rutks is found in relatively few Latvian surnames, 69 instances recorded (Balodis, 2008, p. 189).

The second most oftern encountered vegetable name that is the basis for house names is kapposts (cabbage), with 9 instances recorded. The lexeme kapposts, is found in house names in derivateive form (i. e., Kapostin, Kapoftin, Kapoftin) and in composite form (i. e., Kapoftkaln, Kapuftkaln). House names in Turna private manor were found to be combinations (i. e., Kalne Kappust, Leijes Kappuft). These names J. Endzelinns associates with, possibly, the Estonian term kapust 'cabbage' (Lvv I (2), p. 49).

The appellative kaposts (Brassica oleracea) is found in the first dictionaries of the Latvian language dating from the $17^{\text {th }}$ and $18^{\text {th }}$ centuries (compare, Kapofti 'Kohl', listed in Phras. Lettica, 1638, p. 329, and kahpofti 'Kohl', in Lettus, 1638, p. 104; with Kahpohfts 'Kohl', given by Lange, 1773, p. 138). The Latv. Käposts, the Lith. kopūstas, and the Estonian käbustas are loan words from the Russ. kanycma (ME II, p. 194; see also Sabaliauskas 1990, p. 240; Sehwers, 1953, p. 297; LEV I, p. 379).

The lexeme kapposts as the basis for surnames has been recorded only in 35 instances (Balodis, 2008, p. 188).

House names that derive from the lexeme rācenis (turnip) were recorded in Vidzeme in 8 instances. Alfrēds Rasiņš and Marta Tauriņa indicate that turnip seeds have been found in archaeological material recovered in Latvia dating from the middle Iron age; however, they speculate that turnips may have been cultivated even earlier (Rasiņš \& Tauriņa, 1983, p. 153).

The lexeme rācenis (Brassica rapa) and variants thereof, are found in basic form in house names (i. e., Rahzen, Rahzin, Rahzin,), as well as in derivative forms (i. e., Rahzing, Ratzing), and in composite names (i. e., Kalne Razin, Leies Razin, Rahzing Krug). 
The appellative rācenis is found in the first dictionaries of the Latvian language dating from the $17^{\text {th }}$ and $18^{\text {th }}$ centuries (compare, Ruttkis, Rahzins, listed in 'Rühb' Lettus, 1638, p. 146, and, Rahzini, 'Rüben', in Phras. Lettica, 1638, p. 329; with Rahzinni 'Rüben', given by Lange, 1773, p. 246). The Latvian name for Brassica rapa is dissimilar from names in other languages. Note by way of comparison the appropriate term in other Baltic languages (in Lith., rópẽ), Slavic languages (i. e., Church Slavonic, prona, Russ. péna, Polish, rzepa), Germanis languages (i. e., râba, ruoba), Latin (rāpum, rāpa)

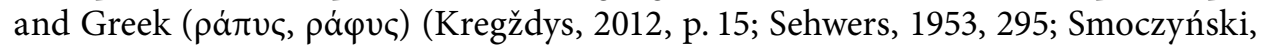
2007, p. 520; LEV II, p. 96).

The lexeme rācenis as the basis for surnames has been recorded only in 39 cases (Balodis, 2008, p. 189).

The lexeme sipols (onion) is the basis for even fewer house names, being recorded in 8 instances. The lexeme sipols (Allium cepa) is only found in basic form in house names with some variations (i. e., Siepol, Sihpohls, Sihpol, Sihpoll, Sipoll). Salt is likely that the house name Zihpol recorded in Umurga derives from the term for onions.

The appellative sipols is found in the first dictionaries of the Latvian language dating from the $17^{\text {th }}$ and $18^{\text {th }}$ centuries (compare, Siepoli 'Zwiebeln', listed in Phras. Lettica 1638, p. 330, and, Siepohls 'Zwiebel', in Lettus, 1638, p. 222; with Sihpoli, tee 'Zwiebeln', given by Lange, 1773, p. 296). The Latvian term for Allium Cepa is a loan word from Middle Low German sipolle (ME III, p. 855; Sehwers, 1953, p. 305; LEV II, p. 184), and the variant cipols, possibly, comes from the German Zipolle (Urbutis, 1981, p. 193).

The lexeme sippols, and variants thereof are found in 47 Latvian surnames (Balodis, 2008, p. 189).

The lexeme kiploks (garlic), as the basis for house names recorded in fewer cases, in 7 instances. This lexeme, kiploks (Allium sativum), is found in basic form, with some variations, in house names (i. e., Kiplok, Kipplok, Kiplohk).

The appellative kiploks is found in the first dictionaries of the Latvian language dating from the $17^{\text {th }}$ and $18^{\text {th }}$ centuries (compare, Kipploki, 'Knoblauch', listed in Phras. Lettica, 1638, p. 330, and in Lettus, 1638, p. 104; with, Ķiplohks, 'Knoblauch', given by Lange, 1773, p. 150). The Latvian term for Allium sativum is a loan word from Middle Low German klüflōk 'garlic' (ME II, p. 383; LEV I, p. 474; Sehwers, 1953, p. 306).

The lexeme kiploks has been recorded to occur in 15 Latvian surnames (Balodis, 2008, p. 188).

House names in a number of manors in Vidzeme are found to include the lexeme burkāns (carrot) in 5 instances. The lexeme burkāns (Daucus carota) is found in basic form in house names (i. e., Burkan), as well as in combined forms (i. e., Kalna Burkan, Leies Burkan).

The appellative, burkanns (carrot), is found in the first dictionaries of the Latvian language dating from the $17^{\text {th }}$ and $18^{\text {th }}$ centuries (see, Burrkanni 'gelbe Rüben', listed 
in Phras. Lettica, 1638, p. 329). The origin for the Latvian term burkāns is obscure. According to Johan Sever, Germans living in Latvia referred to Daucus carota as Burkane, with similar names found in the language spoken by Finnish peoples around the Baltic Sea (Finnish porkkana, Estonian porgand, Livs borkons), as well as in Lithuanian (burkantai, barkunas) and also in Russian (barkán, borkan) (Sehwers, 1953, p. 301; see also LEV I, p. 155). The $20^{\text {th }}$ century dictionary of the Lithuanian language "Lietuvių kalbos žodynas" refers to the loan word bućkonas 'morka (=carrot)', that the compilsers consider to originate from the Latvian burkans which in turn derives from the German dialect term Burkan (LKŽ I, p. 1189).

The lexeme burkāns as the basis for Latvian surnames is found only in 10 instances (Balodis, 2008, p. 187).

It is possible that the lexeme kālis (swede) is the basis for one house name. The lexeme kâlis is found in its basic form in the house name Kahle.

The appellative kâlis is found in the first dictionaries of the Latvian language dating from the $17^{\text {th }}$ and $18^{\text {th }}$ centuries (see, Kahls, kahli 'Wurzelwerk in Gärten' given by Lange 1773, p. 138). The Latvian term kālis, as also the Estonian kaal, is a loan word from Swedish or Middle Low German kål ME II, p. 191 (see, kôl 'Kohl, Gemüse', Schiller II, p. 516), or Low German kāl (LEV I, p. 371; see LEW, p. 281; Urbutis, 1981, p. 210).

The lexeme kālis and variants thereof are rarely foud in Latvian surnames (24 instmaces recorded) although more often than the lexeme burkāns (Balodis, 2008, p. 188).

Plants from the gourd family have been known in Latvia from the $15^{\text {th }}$ century onwards, yet their names have rarely been the basis for house names. Only one house name which could be based on the lexeme gurkis (cucumber, Cucumis), was recorded in the 1826 counting of souls in Vidzeme. This lexeme also is found only in basic form in house name Gurke.

It is unclear, first, when cucumbers were first cultivated extensively in Latvia, and, second, from what time onward the term gurkis came into use. As noted in the oldest dictionaries of the Latvian language, dating from the $17^{\text {th }}-18^{\text {th }}$ centuries, two terms were common, krievu äbols (compare, Kreewahbohli, 'Gurcken', listed in Phras. Lettica, 1638, p. 330; with kreewu ahboli 'Agurken', given by Lange, 1773, p. 157) and, gurkis (compare, Gurki, 'Gurken, Kreew ahboli', as given by Fürecker I, p. 80; with gurkis 'Gurke', listed by Stender, 1789, p. 84). In Latvian the lexeme gurkis is a loan word. J. Sever speculates that the Low German terms agurke, augurke are the source for the Latvian terms agurkis, augurkis, that subsequently transformed into the term gurkis (Sehwers, 1953, p. 302). Konstantins Karulis states that the source term was the German word Gurke (LEV I, p. 326).

The lexeme gurkis is found in only 5 Latvian surnames (Balodis, 2008, p. 188)

One house name has been recorded that might be based on the lexeme kabacis (summer squash, Cucurbita). The house name may have incorporated the lexeme kabacis in variant form Kabbajch. 
This explanation appears to be unlikely as the appellative kabacis is not found in any historical dictionaries of the Latvian language. It is first listed in Latvian dictionaries from the mid- $20^{\text {th }}$ century. The Latvian term might be a loan word from a Slavic language (compare, Russ., Old Russ. кабачок with Pol. kabaczek).

Superficially the house name Rappfche recorded in Vestiena private manor to be related to the modern term for the oilseed plant rapsis (colza, Brassica napus).

The lexeme, rapsis, is found in the dictionary compiled by Carl Christian Ulmann (see, rapfchi 'der Raps', listed by Ulmann, 1872, p. 220).

\section{Names of fibre-producing plants}

House names also derive from terms for widely-cultivated plants such as kanepes (hemp), apini (hops) and lini (flax). Thes have been the basis for 40 house names, which represent $7 \%$ of all hosue names based on floral semantics. Hops are mentioned and praised in folklore and folk sayings; the lexeme is the basis for 26 house names. Seeds for hops have been found in layers dating from the $11^{\text {th }}-13^{\text {th }}$ centuries (Rasiñ \& Taurina, 1983, p. 154); thus, it is likely that hops have been cultivated in Latvija from at least the early $2^{\text {nd }}$ millennium onwards (Lat vijas senākā vēsture, 2001, p. 319).

The lexeme kan,epe (Cannabis) is found in basic form in house names (i. e., Kañep, Kannep, Kannepe), as well as in derivative forms (i. e., Kanepen, Kannepen) and composite forms (i. e., Kaln Kannepe, Kalne Cannepe, Kalne Cannnepe, Leies Cannepe, Leies Cannnepe, Leis Kannepe, Kannep Land), and combined forms (i. e., Jaun Kannepen).

The appellative kan,epāji is found in the first dictionaries of the Latvian language dating from the $17^{\text {th }}$ and $18^{\text {th }}$ centuries (compare, Kannnepeji 'Hanff', listed in Phras. Lettica, 1638, p. 329, with Kannepeji 'Hanff', in Lettus, 1638, p. 84). T. Gamkrelidze and V. Ivanov consider that various terms designating hops originate from Old European Indo-European dialects (Гамкрелидзе \& Иванов, 1984 (2), p. 662). Several views are current about the way that this term appeared in the Latvian language. The term may be a loan word from the Scythian language, or from a Slavic language (see, ME II, p. 157; Sabaliauskas, 1990, p. 239; LEV I, pp. 377, 378).

P. Balodis records the lexeme kañepe in 53 surnames (Balodis, 2008, p. 188).

In Vidzeme fewer house names are based on the lexeme apini (11 instances recorded).

The lexeme apinis (Humulus) is found in basic form in house names (i. e., Appen, Appin, Appin, Apping $(c h)$, as well as in derivative forms (i. e., Apping, Appineek), and combined forms (i. e., Apping Jahn, Apping Peter).

It is likely that the house names Appenas and Leische Appenas, recorded in Koknese Parish are based on the lexeme apinājs, also apenājs, that designates not the plant itself but a field of hops or hops growing on the vine. 
The appellative apinis is found in the first dictionaries of the Latvian language dating from the $17^{\text {th }}$ and $18^{\text {th }}$ centuries (compare, Appini 'Hopffen', listed in Phras. Lettica, 1638, p. 331; with Appini, tee 'der Hopfen', given by Lange, 1773, p. 22). A specific designation for Humulus has originated in Latvian and Lithuanian based on the verb $v i t$. The most likely original form of the term is *apvinis (see ME I, p. 90; LEV I, p. 71; Sehwers, 1953, p. 309; Smoczyński, 2007, p. 20; Kregždys, 2012, p. 34). J. Endzelīns rejected the hypothesis due to A. Bezzenberger that the Latvian term apiņi, from the German terms hoppe, or Hopfen (ME I, p. 90).

The lexeme apinis in Latvian surnames has been recorded 75 times (Balodis, 2008, p. 187).

Although flax has been long cultivated in Latvia to a significant extent the lexeme lini (Linum) is the basis for rather few house names ( 3 instances recorded). The lexeme lins is found in basic form in house names (i. e., Lines), as well as derivative forms (i. e., Linning). The house name Linnai, may be the lexeme linājs, that does not refer to the plant itself, but rather to a field of flax or such a field after the crop has been taken in, or flax stalks. Is it also possible that conditions were not suitable during the $19^{\text {th }}$ century to cultivate flax in Vidzeme? Stories about flax and its treatment have survived until today.

The appellative lins is found in the first dictionaries of the Latvian language dating from the $17^{\text {th }}$ and $18^{\text {th }}$ centuries (compare, Linni 'Flacks', listed in Phras. Lettica, 1638, p. 328, Linni 'Flachs', in Lettus, 1638, p. 60; with Linni, tee 'Flacks', given by Lange, 1773, p. 178); in all Baltic languages the term has retained the ancient Indo-european root, *lĭno-, from which there developed the Latv. term lins, the Lith. linai, Prussian lynпо (Гамкрелидзе \& Иванов, 1984 (2), p. 659; see also, Sabaliauskas, 1990, p. 41; Kregždys, 2012, p. 15).

The lexeme lins may be discerned in 50 Latvian surnames (Balodis, 2008, p. 188).

\section{Names of other herbs}

House names are also based on the names of a number of cultivated and wild herbal plants, even of a number of garden weeds. A total of 47 such cases have been recorded, corresponding to $8,2 \%$ of all house names based on floral semantics.

Among the lexemes in this category, the term dadzis (thistle) has been found most frequently, a total of 11 cases recorded. The lexeme dadzis (Arctium) is found in its basic form in house names (i. e., Dadfe, Dadfche), as well as derivative forms (i. e., Dadfiht, Dadfehn, Dadsing), and combined forms (i. e., Jaun Dadsing, Wetz Dadsing).

The appellative dadzis is found in the first dictionaries of the Latvian language dating from the $17^{\text {th }}$ and $18^{\text {th }}$ centuries (compare, Dadfis/Dadfchi 'Kletten', listed in 
Phras. Lettica, 1638, p. 331, and Dadfis 'Kletten', in Lettus, 1638, p. 103; with, Dadfchi, tee 'Kletten', given by Lange, 1773, p. 70). The Latv. term dadzis, the Lith. dagỹs, belong to the that part of the lexicon, that in derivative form and semantically correlates with equivalents only in eastern and western Baltic languages (Kregždys, 2012, p. 34); these terms may have evolved from the Latv. term degt, the Lith. dègti (ME I, p. 429; Sabaliauskas, 1990, p. 155).

House names based on a multitude of forms based on the terms for āboliňs (clover), and amoliņs (sweet clover) are found in Vidzeme in 10 instances.

$\bar{A}$ boliņš (Trifolium) refers to a genus that belongs to the leguminous pea family, whereas amoliņ̌s (Melilotus), is a different genus in the same family. In everyday situations the terms are sufficiently similar that their use is mixed and may be confusing.

Three house names have been recorded in Vidzeme, Aboling, Aboltin and Abulting, correlate with the root $\bar{a} b o l-/ \bar{a} b u l-$. Two house names, of which one is in its basic form (Ammol), and the other in derivative form (Amoling) correlate with another root - amol-.

Both the term for clover (compare, Ahbolites 'Klee', listed in Phras. Lettica 1638, 331; with Abolini/Ahbola=fahle 'Kleegraß', in Phras. Lettica, 1638, p. 328, Ahbolifchi/ Ahbola a=fahle 'Klee', in Lettus, 1638, p. 103; and Ahboles, ahbolites, ahbolini, 'Klee', given by Lange, 1773, p. 4), as well as its variants (see, Amuls 'der Klee', given by Fürecker I, p. 16) are found in the historical dictionaries of the Latvian language. An unclear explanation is offered in the dictionary compiled by Jacob Lange for a related lexeme (see, Ahmalls 'ein Kleeanger', Lange, 1773, p. 5). It is possible that this term might refer to clover (amolinšs); however, the translation is offered of āmals, as a field of clover. Various explanations are current for the origin of both of these phytolexemes - āboliňs $\check{\text { and }}$ amolins. The most widely accepted explanation is that the Latv. ābolin, š has evolved influenced by the Latv. term àbols from the older the Latv. term dābols, the Lith. dóbilas, the Prussian wobilis, which are found only in Baltic languages and are based on the Indo-European term *dheb- 'thick, close, stocky' (Kregždys, 2012, p. 34; Sabaliauskas, 1990, p. 155; LEV I, p. 194). Another term for Trifolium, i. e., amols, amolinšs is formally identical with variants of the semantically different phytolexeme àmulis (Viscum), for which parallel forms are found in Baltic languages (Lith. ãmalas, emalas, Prussian етеlno), and Slavic languages (i. е., Pol. jemioła, Old Russ. омела, Russ. оме́ла, Russ. ямели́на) (for detailed arguments see Kregždys, 2012, pp. 26-33).

A further three house names (Ebbel and Ebul/Eebul) may be based on dialect variations of the root ebul-/ ebol-. As late as in the second half of the $20^{\text {th }}$ century variants were known in Vidzeme based on the root ebul-/ ebol-, as given in the compilation of variations on common speech in Ērǵeme Ērǵemes izloksnes vārdnīcas (see, ębuôls, and êbùls 'clover' ËIV I, p. 309).

The lexeme ābolinšs together with its variants is found rather often in Latvian surnames, with a total of 308 cases recorded (Balodis, 2008, pp. 186, 187). 
House names based on the term for the herb dille (dill) are almost as widespread with 6 instances recorded. The lexeme dille (Anethum) is found in derivative forms in house names (i. e., Dillit, Dillen) and composite form (i. e., Jaun Dille, Wetz Dille). The Latv. term dilles is a loan word from Low German dill (Sehwers, 1953, p. 305; see also LEV I, p. 219).

The appellative dille is found in the first dictionaries of the Latvian language dating from the $17^{\text {th }}$ and $18^{\text {th }}$ centuries (compare, Dilles 'Dillen', listed in Phras. Lettica 1638, p. 330, and Dilles 'Dille', in Lettus, 1638, p. 48; with, Dilles, tahs 'Dillkraut', given by Lange, 1773, p. 79).

The lexeme dille is found only in 4 Latvian surnames (Balodis, 2008, p. 187).

In addition a number of house names are found during the first half of the $19^{\text {th }}$ century in Vidzeme that are based on terms for grass-like plants growing in fields and swamps.

A number of house names ( 3 instances recorded) are based on the lexeme, grisslis (sedge). The lexeme grisslis is found in its basic form in house names (i. e., Griesle), and combined forms (i. e., Kalne Grifle, Leies Grifle).

The appellative grissis is found in the first dictionaries of the Latvian language dating from the $17^{\text {th }}$ and $18^{\text {th }}$ centuries (see, Grih/lis, tas 'grob oder Riedgras', given by Lange, 1773, p. 123). Konstantins Karulis considers that the basis for the Latvian appellative grislis is the verb * grizt, 'to cut, to weave' (LEV I, p. 317).

Several house names, 5 instances recorded, are based on the lexeme smilga (bent grass). The lexeme smilga (Agrostis) is found in its basic form in house names (i. e., Smilgas, Smilge) and in composite form (i. e., Smilgakrug).

The appellative smilga is found in the first dictionaries of the Latvian language dating from the $17^{\text {th }}$ and $18^{\text {th }}$ centuries (see, Smilgas, tahs ' $T a u=S c h m e e l=$ gras', given by Lange, 1773, p. 311). The origin is unclear of the Latv. term smilga, the Lith. smilga; it may be based either on the Indo-European verb, *mel-, 'to rub, to push, to cut-up', or on the Lith. term smelkiù, smelkti (LEV II, p. 243; Smoczyński, 2007, p. 577).

The appellative smilga in Latvian surnames is found in 93 recorded instances (Balodis, 2008, p. 185).

Only two house names have been recorded that are based on the phytolexeme usne (creeping thistle, Cirsium arvense). The lexemes usne, and ušne are only found in their basic form in house names (i. e., Usne, Uschne).

The appellative usne (or one of its variants) has only been found in historical dictionaries of the Latvian language only during the second half of the $19^{\text {th }}$ century (see, Diftel 'gufchṇa, gufchñis, gufchṇi, ufchṇi', given by Ullmann, 1880, p. 196); however, in house names it is noted no later than the early $19^{\text {th }}$ century. There are several views concerning the origin of this term. It may be based on the Indo-Europeam verbs, *ues-, 'to jab', or, *eus : *us-, 'to burn' (LEV II, pp. 458, 459).

It is possible that the house names (Peenes, Peenehn) found in Vidzeme are based on the term for dandelion (Taraxacum), with the different lexemes piene and pienene, 
which are listed in historical Latvian dictionaries starting only from the mid-19 $9^{\text {th }}$ century onwards (see, peenes, 'alle dem Löwenzahn ähnliche Blumen', and peenene 'für peenes', given by Ullmann, 1872, p. 195). The Latv. terms piene, pienene and the Lith. piẽnẽ are based on the term for milk piens. Similar explanations for terms describing Taraxacum obtain for Slavic languages (Jansone, 2011).

The possibility cannot be excluded that these house names are not based on the appellatives piene and pienene, but upon the appellative piens (milk).

It is moore problematic to explain the basis for two house names Pehrkohn, Perkohn recorded in Pink,i Parish; it is possible to relate these house names with the term for charlocks (pérkone, Raphanus raphanistrum), a term that has been mentioned in later $19^{\text {th }}$ century dictionaries with several meanings (see, pehrkones 'Hederich, Eryfimum officinale, Sinapis arvenfis, Raphanus Raphaniftrum', as given by Ullmann, 1872, p. 197). It is possible that the Latv. perrkone is related to weather phenomena perrkons (thunder), or the name of the principal Baltic deity (LEV II, pp. 38, 39).

It might be more credible to relate these house names either to the weather phenomenon or the name of the ruler of the heavens Perrkons.

Only two house names have been recorded in Vidzeme that it is possible to relate to the lexeme niedre (reed). The house name Needrehn is based on a derivative form.

The appellative niedra (Phragmites) is found in the first dictionaries of the Latvian language dating from the $17^{\text {th }}$ and $18^{\text {th }}$ centuries (compare, Needra 'Rietrohr', listed in Lettus, 1638, p. 145; with, Needrs, tas 'das Rohr', given by Lange, 1773, p. 219). This appellative is part of the common lexicon for Baltic languages (compare, the Latv. term niedre with the Lith. néndré), and these are semantically and as derivations correlated only with terms in the eastern and western Baltic languages (Kregždys, 2012, p. 34; see also, Smoczyński, 2007, p. 419).

The lexeme niedra in Latvian surnames has been recorded in 57 instances (Balodis, 2008, p. 185).

The lexeme skosta (horse-tail) may possibly have been the basis for a single house name Skohfte, the lexeme appearing in an underived form.

The appellative skosta (Equisetum) is found already in Latvian language dictionaries from the $18^{\text {th }}$ centuries (see, fkohftas, fkohftines 'Spargel', given by Lange, 1773, 303). The origin of the Latv. term skosta, i. e. kosa, is unclear: two unconvincing arguments are due to K. Karulis (see, LEV I, p. 415).

It is possible that the lexeme vinbotne (mugwart) is the basis for the single house name Wieboth.

The appellative vîbote (Artemisia) is found in the first dictionaries of the Latvian language dating from the $17^{\text {th }}$ and $18^{\text {th }}$ centuries (compare, Wiebotes 'Beyfuß', listed in Phras. Lettica, 1638, p. 330, and Biebotes/Wiebotes 'Beyfuß', in Lettus, 1638, p. 30; with Wihbotes, tahs 'Beyfuß', given by Lange, 1773, p. 389). J. Endzelīns remarked (ME IV, p. 634) that the Latv. term vîbote [vībuote] was form as the result of dissimilation 
either from the term bībuotes (a loan word from Middle Low German bibot), or the term bivuotes (a loan word from Middle Low German bifot).

Names found in this group, and which are the basis for several house names, possess a neutral connotation; thus, their choice might have related to the presence nearby of the associated plants, whereby the house could be identified, or the choice has been random.

\section{Names of flowers}

In Latvian folklore what is positive is usually contrasted with that which is undesirable (that is criticised through through song). Flowers have always decorate homesteads. A total of 32 house names based on three flower terms, roze (rose), magone (poppy) and astere (aster) have been recorded; this represents 5,6\% of all house names based on floral semantics. The majority (26) of these house names are based on terms for roses, However, one must remark that it is impossible to distinguish cases where the house name is based on the term for the flower from those based on the Latvian term roza (a rise) for a feature in the landscape.

The lexeme roze (Rosa) is found in its basic form in house names (i. e., Rohse, Rohfe, Rofe), as well as in derivative forms (i. e., Rohfit, Roefit, Rohfin, Rohsen, Rohsneek, Rohfnen, Rohfuk, Aisrohs), in composite forms (i. e., Augstrohfe, Augstrofe, Esferohse) and combined words (i. e., Jaun Rohse, Wezz Rohse), and other combined forms (i. e., Jaun Rosnek, Lel Rofen, Mas Rofen). The Latvian term roze is a loan word from Middle Low German term rōse, or Old High German rōsa (Sehwers, 1953, p. 313; LEV II, p. 132).

The appellative roze is found in the first dictionaries of the Latvian language dating from the $17^{\text {th }}$ and $18^{\text {th }}$ centuries (compare, Rohfe 'Rofe', listed in Lettus, 1638, p. 145; with Rohfe 'die Rofe', given by Lange, 1773, p. 252).

The presence of the appellative roze has been identified in 197 Latvian surnames (Balodis, 2008, p. 185).

House names, based on other terms for flowers, 5 cases referring to magones (poppies) have been recorded in Jaunpiebalga Parish. The lexeme magone (Papaver) appears in house names only in combined form (i. e., Kalne Maggon, Leies Maggon). Poppies have been grown in the territory of Latvia, at least during the $11^{\text {th }}-13^{\text {th }}$ centuries (Rasiňš \& Tauriņa, 1983, p. 154); however, the descriptive term is found first in an $18^{\text {th }}$ century dictionary (see, Maggone 'der Mohn', given by Lange, 1773, p. 182). Lexical parallels for the Latvian term magone are found in Baltic, Slavic and German languages, yet the origin of these terms is obscure (Kregždys, 2012, p. 34, see also, Sehwers, 1953, p. 312; LEV I, pp. 557, 558).

The lexeme magone is only occasionally present in Latvian surnames, with 20 instances recorded (Balodis, 2008, p. 185). 
A number of house names in Vidzeme appear to be based upon astere (aster); however houses located in Umurga Parish named Astere or Ästere may derive ther name from that of a near-by Manor (Aster - Rozbeku private house, Straupe Parish, see, LVVA, p. 199. f., 1. apr, 383. 1.) the origin of whose name may not necessarily be the name of the flower astere.

Based on the etymological work of the Lithuanian linguist Kazimieras Būga, Jānis Endzelīns (see, Lvv (1), p. 70), considers that this place name and that of an associated hydronym is based on an archaic Liv. Asti-yerwe. After analysis of old documentary records of various hydronyms $\mathrm{K}$. Büga concluded that modern terms ending in,-ere, are concealed indicators of the Finno-Ugric term, järv 'lake' (Būga RR III, p. 622). If one accepts the hypothess advanced by K. Būga, the name of Āstere Manor originates from the name of a near-by lake.

If the name of Āstere Manor is based on a hydronym, then a similar argument may be advanced for the basis of house names in Straupe Parish. These house names, furthermore, may be based not on the name of a lower, but on the latin term astrum 'star'.

\section{Names of mushrooms}

As is the case for surnames, a number of house names in Vidzeme appear to be based on names of mushrooms. Only 6 such names have been recorded, which represent $1 \%$ of all house names based on floral semantics. The largest number (4 instances recorded) of such names are based on the terms bekas (boletus), as well as pekas.

The lexeme beka is found in its basic form in house names (i. e., Bekke), as well as in combined form (i. e., Bekka Krug). The composite name Sillapek $a^{9}$ can be variously understood, firstly, as a joined word, or, alternatively referring to a particular type of mushroom, which latter is thus named.

The appellatives beka and peka are found in the first dictionaries of the Latvian language dating from the $17^{\text {th }}$ and $18^{\text {th }}$ centuries (see, Bekkas, tahs [Stein] 'Ritzchen', given by Lange, 1773, p. 55, and Pekki 'Kuhpiltzen', also in Lange, 1773, p. 233). The Latvian term beka (also peka) is traditionally viewed to be a loan word from the Liv language, i. e., $p \ddot{a} k \bar{a}$ 'mushroom', or Estonian päkk 'mushroom' (ME III, p. 193, see also, LEV II, p. 33).

The appellative beka is discernible in only 7 Latvian surnames (Balodis, 2008, p. 190).

The names for two mushroom species krimilde, and rudmiese (Lactarius) are the basis for house names, i. e., Krimalden, recorded in Valmiera Parish, and Rudmes in Nitaure Parish.

\footnotetext{
9 Trans. Note, this name contains the term sils (field or clearing).
} 
Both the term krimildes (ref., Krimmeldes, 'eine Art weißer Rietzchen', given by Lange, 1773, p. 158), and rudmieses (ref., Rudmeefchi, 'braune Rietzchen', also given by Lange, 1773, p. 253), were known during the second-half of the $18^{\text {th }}$ century. Thus, they could have been the basis for house names, as a possible indication that these houses were sited close to a forest where these mushrooms grew. The Latv. rudmiese might be a term that is semantically derived from the Latv. term ruds (reddish) and the Latv. term miesa (flesh, ME III, p. 554), whereas the terms krimilde, krimelde (as a mushroom) may be associated with the Latv. terms kremîgs, krama, kramt (ME II, p. 279).

The variant $k$ rimelis found in a few Latvian surnames ( 5 instances), may be associated with krimilde, the mushroom (Balodis, 2008, p. 190).

House names listed in the 1826 counting of souls are based on a wide range of floral semantics, with a clear preference for lexemes associated with names of trees. It is possible that this reflects landscape elements close to these homes, as well as the place that these features have in the relationship of home owners with nature, and their work in order to draw any deeper conclusions about the presence of floral semantics in house names it would be necessary to examine all relevant historical records in detail up to and including the present time.

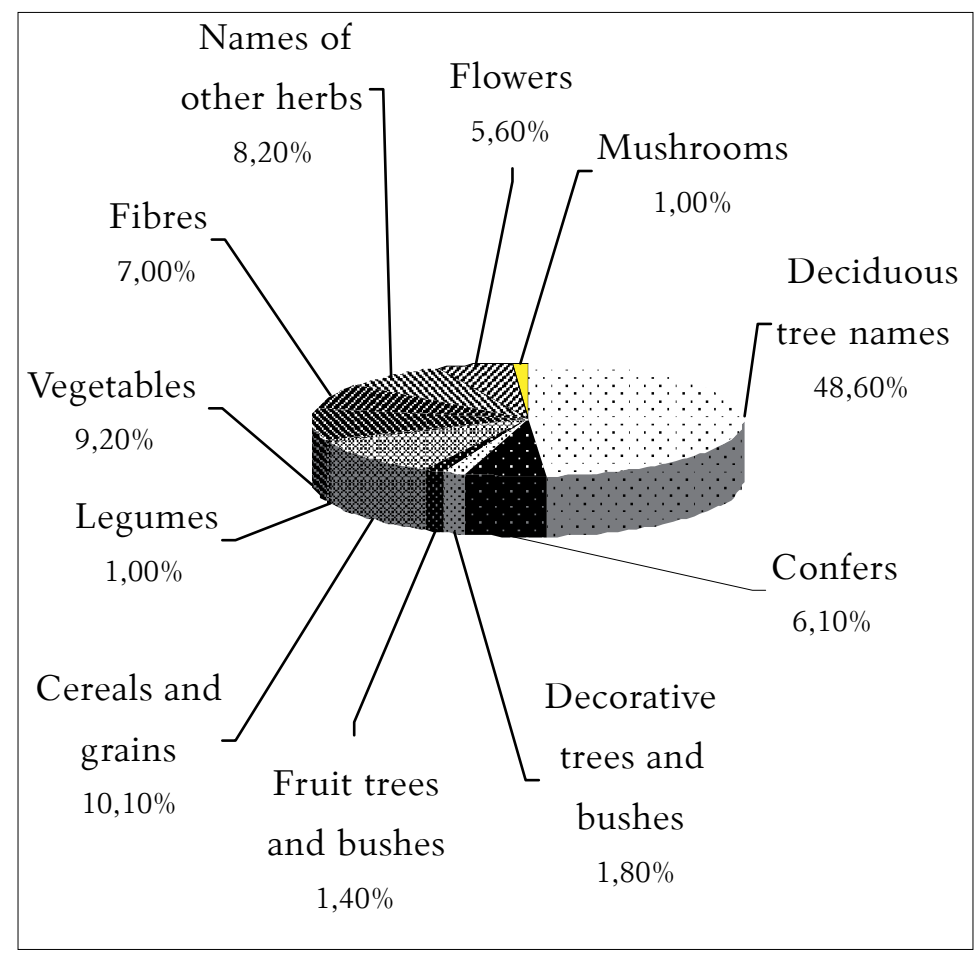

Figure 3. Groups of phytolexemes reflected in house names 
Ilga Jansone On flora semantics in house names found in Vidzeme: materials contained in the $1826 \ldots$

\section{Primary sources}

LVVA 199. fonds [foundation], 1. apraksts [description] (counting of souls in Vidzeme)

\section{Abbreviations and literature}

Balode 2012 - Balode Laimute. Liepa latviešu onomastiskajā kontekstā. - Inkluzīvi. Sast. Janīna Kursīte. Rīga: LU Akadēmiskais apgāds, 2012, 321.-355.

Balodis 2008 - Balodis Pauls 2008, Latviešu personvārdu etimoloğiskās semantikas teorētiskais modelis un tā realizācija. Promocijas darbs. Rīga: Latvijas Universitāte.

Būga RR III - Kazimieras Būga. Rinktiniai raštai 1-3, Vilnius: Valstybinè politinès ir mokslinès literatūros leidykla, 1958-1961.

Bušs 2012 - Bušs, Ojārs. Dažas pārdomas par ozolu Latvijas toponīmiskajā panorāmā un geogrāfiskās nomenklatūras vārdu kontekstā. - Apvienotais Pasaules latviešu zinātnieku III kongress un Letonikas IV kongress "Zinātne, sabiedrība un nacionālā identitāte”. Valodniecības raksti. Rīga: LU Latviešu valodas institūts, 2012, 121.-129.

BW - Krišjānis Barons, Henrijs Visendorfs. Latvju dainas 1-6, Jelgava-Pēterburga, 1894-1915.

ĒIV - Kagaine Elga. Ērğemes izloksnes vārdnīca. 3. sēj. P-Ž. Rīga: Zinātne, 1983.

Graudonis 1989 - Graudonis Jānis. Nocietinātās apmetnes Daugavas lejtecē. Rīga: Zinātne, 1989, 72.-73. lpp.

Fürecker I - Lettisches und Teutsches Wörterbuch zusahmen geschrieben und mit fleiß gesamlet Von Christopher Fürecker. - Trevor G. Fennell. Fürecker's dictionary: the first manuscript, Rīga: Latvijas Akadēmiskā bibliotēka, 1997 [1685].

Hirša 1990 - Hirša Dzintra. Koku, mežu un krūmu nosaukumi Sarkanmuižas (Ventas) vietvārdos. - Onomatica Lettica. Rīga: Zinātne, 102.-148. lpp.

Jansone 2011 - Jansone Ilga. Pienenes (Taraxacum) nosaukumi. - Humanitāro Zinātņu Vēstnesis, Nr. 19. Daugavpils Universitāte, 2011, 35.-50. lpp.

Kettunen - Livisches Wörterbuch mit grammatischer Einleitung von Lauri Kettunen. Helsinki: Suomalais-ugrilainen seura, 1938.

Kregždys 2012 - Kregždys Rolandas. Kopīgā baltu valodu leksika: flora. - Baltu valodu atlants / Baltų kalbu atlasas / The Atlas of the Baltic Languages. Sastādītājas / Sudarytojas / Editing by: Danguolè Mikulènienė (Lietuva), Anna Stafecka (Latvija). Vilnius: Lietuvių kalbos institutas, 2012. (CD-ROM)

Lange 1773 - Lettifch-Deutfcher Theil des volftändigen Lettifchen Lexici, darinnen nicht nur sämtliche Stammwörter diefer Sprache famt ihren Abftämlingen, fondern auch die feltene, nur in gewißen Gegenden gebräuchliche Wörter, zum Nachfchlagen, angezeigt werden. Schloß Ober//Pahlen, 1773.

Lettus 1638 - LETTUS, Das ift Wortbuch / Sampt angehegtem täglichem Gebrauch der Lettifchen Sprache; / Allen vnd jeden Außheimifchen / die in Churland / Semgallen 
Ilga Jansone On flora semantics in house names found in Vidzeme: materials contained in the $1826 \ldots$

vnd Lettifchem Liefflande bleiben / vnd fich redlich nehren wollen / zu Nutze verfertigt / Durch / GEORGIVM MANCELIVM Semgall. der H. Schrifft Licentiatum \&c. Erster Theil. Gedruckt vnnd verlegt zu Riga / durch Gerhard Schröder / Anno M. DC XXXVIII [1638].

LEV -Karulis Konstantīns. Latviešu etimoloǵijas vārdnīca 1-2, Rīga: Avots, 1992.

LEW - Ernst Fraenkel. Litauisches etymologisches Wörterbuch 1-2, Heidelberg: Carl Winter Universitätsverlag, Göttingen: Vandenhoeck \& Ruprecht, 1955-1962.

LKŽ I - Lietuvių kalbos žodynas. I, A-B. Antras leidimas. Vilnius: Minties, 1968.

LVDA - Brigita Bušmane, Benita Laumane, Anna Stafecka. Latviešu valodas dialektu atlants. Leksika. Darba zin. vad. B. Laumane, Rīga: Zinātne, 1999.

Lvv I - Endzelīns Jānis. Latvijas PSR vietvārdi 1(2), Rīga: Latvijas PSR Zinātṇu akadēmijas izdevniecība, 1961.

ME I-IV, Mīlenbahs Kārlis. Latviešu valodas vārdnīca. Redig̣ējis, papildinājis, turpinājis J. Endzelīns. 1.-4. sēj., R., 1923.-1932.

Ortslexikon - Baltisches historisches Ortslexikon. II. Lettland. Hrsg. von Hans Feldmann und Heinz von zur Muhlen, Koln-Wien, 1990.

Phras. Lettica 1638 - Phraseologia Lettica / Das ist: Täglicher Gebrauch der Lettischen Sprache. Verfertigt / durch Georgium Mancelium Semgallum / Der H. Schrifft Licentiatum \&c. Ander Theil. Diesem ist beygefüget das Spruchbuch Salomonis. Zu Riga Gedruckt vnnd Verlegt durch Gerhard Schröder / 1638.

Rasiņš \& Tauriṇa 1983 - Rasiṇš Alfrēds, Tauriṇa Marta. Pārskats par Latvijas PSR arheolog̣iskajos izrakumos konstatētajām kultūraugu un nezāḷu sēklām. Arheologiija un etnogrāfija, 14. laid., 1983, 171. lpp., 10. tab.

Sabaliauskas 1990 - Sabaliauskas Algirdas. Lietuvių kalbos leksika, Vilnius: Mokslas, 1990.

Salis-Livischen 2009 - Salis-Livisches Wörterbuch. Herausgegeben von Eberhard Winkler und Karl Pajusalu. Linguistica Uralica. Supplementary series. Volume 3. Tallinn: Teaduste Akadeemia Kirjastus, 2009.

Schiller I-VI -Schiller Karl, Lübben August. Mittelniederdeutsches Wörterbuch1-5, Bremen: Verlag von J. Kühtmann's Buchhandlung, 1875-1880; 6, Bremen: Verlag von Hinricus Fischer, 1881.

Sehwers 1953 -Sehwers Johannes. Sprachlich-kulturhistorische Untersuchungen vornehmlich über den deutschen Einfluß im Lettischen, Berlin, 1953.

Smoczyński 2007 - Smoczyński Wojciech. Słownik etymologiczny języka litewskiego. Vilnius: Vilniaus universiteto leidykla, 2007.

Staltmane 1981 - Сталтмане Велта, Латышская антропонимия. Фамилии. Москва: Наука.

Stenders 1789 - Lettisches Lexikon. In zween Theilen abgefasset, und den Liebhabern der lettischen Litterature gewidmet von Gotthard Friedrich Stender. Lettisches Wörter- und Namen-Lexikon. Erster Theil. Mitau: J. F. Steffenhagen, 1789.

Ulmann 1872 - Lettisches Wörterbuch. Erster Theil. Lettisch-deutsches Wörterbuch von Bischof Dr. Carl Christian Ulmann. Riga: Verlag von H. Brutzer \& Co, 1872. 
Ilga Jansone On flora semantics in house names found in Vidzeme: materials contained in the $1826 \ldots$

Ullmann 1880 - Lettifches Wörterbuch von Ulmann und Brafche. Zweiter Theil. Deutfch-lettifches Wörterbuch mit Zugrundelegung des von Bifchof Dr. Carl Chriftian Ulmann zurükgelaffenen Manufcriptes bearbeitet von Guftav Brafche, Paftor emer., Riga u Leipzig, 1880..

Urbutis 1981 -Urbutis Vincas. Baltu etimologijos etiudai, Vilnius: Mokslas, 1981.

Wied. - Wiedemann Ferdinand Johann. Eesti-saksa sönaraamat. Tallinn: Valgus, 19734.

Гамкрелидзе \& Иванов 1984 - Тамаз В. Гамкрелидзе, Вячеслав В. Иванов. Индоевропейский язык и индоевропейцы 1-2, Тбилиси: Издательство Тбилисского университета, 1984.

\section{Bibliography}

Balode, L. (2012). Liepa latviešu onomastiskajā kontekstā. In J. Kursīte (Ed.), Inkluzīvi (pp. 321-355). Rīga: LU Akadēmiskais apgāds.

Balodis, P. (2008). Latviešu personvārdu etimologiskās semantikas teorētiskais modelis un tā realizācija. Promocijas darbs. Rìga: Latvijas Universitāte.

Barons, K., \& Visendorfs, H. (1894-1915). Latvju dainas [BW] (Vol. 1-6). Jelgava-Pēterburga.

Būga, K. (1958-1961). Rinktiniai raštai [Būga RR III] (Vol. 1-3). Vilnius: Valstybinè politinès ir mokslinès literatūros leidykla.

Bušs, O. (2012). Dažas pārdomas par ozolu Latvijas toponīmiskajā panorāmā un geogrāfiskās nomenklatūras vārdu kontekstā. In Apvienotais Pasaules latviešu zinātnieku III kongress un Letonikas IV kongress „Zinātne, sabiedrība un nacionālā identitāte“. Valodniecības raksti (pp. 121-129). Rīga: LU Latviešu valodas institūts.

Endzelīns, J. (1961). Latvijas PSR vietvārdi [Lvv I] (Vol. 1(2)). Rīga: Latvijas PSR Zinātṇu akadēmijas izdevniecība.

Feldmann, H., \& Zur Muhlen, H., von (Eds.). (1990). Baltisches historisches Ortslexikon: II. Lettland [Ortslexikon]. Köln: Böhlau.

Fraenkel, E. (1955-1962). Litauisches etymologisches Wörterbuch [LEW] (Vol. 1-2). Heidelberg: Carl Winter Universitätsverlag.

Fürecker, C. (1997). Lettisches und Teutsches Wörterbuch zusahmen geschrieben und mit fleiß gesamlet von Christopher Fürecker [Fürecker I]. In T. G. Fennell, Fürecker's dictionary: the first manuscript. Rīga: Latvijas Akadēmiskā bibliotēka.

Graudonis, J. (1989). Nocietinātās apmetnes Daugavas lejtecē. Rīga: Zinātne.

Graudonis, J., \& Apals, J. (Eds.). (2001). Latvijas senākā vēsture: 9. g.t. pr. Kr.-1200. g. [Latvijas senākā vēsture]. Rīga: Latvijas vēstures institūta apgāds.

Hirša, D. (1990). Koku, mežu un krūmu nosaukumi Sarkanmuižas (Ventas) vietvārdos. In Onomatica Lettica (pp. 102-148). Rīga: Zinātne.

Jansone, I. (2011). Pienenes (Taraxacum) nosaukumi. Humanitāro Zinātņu Vēstnesis, (19), 35-50.

Kagaine, E. (1983). Érǵemes izloksnes vārdnīca [ĒIV] (Vol. 3: P-Ž). Rīga: Zinātne.

Karulis, K. (1992). Latviešu etimoloğijas vārdnīca [LEV] (Vol. 1-2). Rīga: Avots. 
Ilga Jansone On flora semantics in house names found in Vidzeme: materials contained in the $1826 \ldots$

Kettunen, L. (1938). Livisches Wörterbuch mit grammatischer Einleitung von Lauri Kettunen. Helsinki: Suomalais-ugrilainen seura.

Kregždys, R. (2012). Kopīgā baltu valodu leksika: flora Danguolè. In D. Mikulènienè \& A. Stafecka (Eds.), Baltu valodu atlants [Baltų kalbų atlasas; The Atlas of the Baltic Languages]. Vilnius: Lietuvių kalbos institutas.

Lange, J. (1773). Lettifch-Deutfcher Theil des volftändigen Lettifchen Lexici, darinnen nicht nur sämtliche Stammwörter diefer Sprache famt ihren Abftämlingen, fondern auch die feltene, nur in gewißen Gegenden gebräuchliche Wörter, zum Nach/chlagen, angezeigt werden. Schloß Ober//Pahlen.

Laumane, B., Bušmane, B., \& Stafecka, A. (Eds.). (1999). Latviešu valodas dialektu atlants: Leksika [LVDA]. Rīga: Zinātne.

Lietuviu kalbos žodynas [LKŽ I]. (1968) (Vol. I: A-B. Antras leidimas). Vilnius: Minties.

LVVA 199. fonds [foundation], 1. apraksts [description] (counting of souls in Vidzeme) [LVVA 199]. (n.d.).

Mancelius, G. (1638). Lettus, Das ift Wortbuch / Sampt angehegtem täglichem Gebrauch der Lettifchen Sprache; / Allen vnd jeden Außheimifchen / die in Churland / Semgallen vnd Lettifchem Liefflande bleiben / vnd fich redlich nehren wollen / zu Nutze verfertigt / Durch / GEORGIVM MANCELIVM Semgall. der H. Schrifft Licentiatum \&c. Erster Theil. Gedruckt vnnd verlegt zu Riga / durch Gerhard Schröder / Anno M. DC XXXVIII [Lettus].

Mancelius, G. (1638). Phraseologia Lettica: das ist: Täglicher Gebrauch der Lettischen Sprache. Diesem ist beygefüget das Spruchbuch Salomonis [Phras. Lettica]. Riga: Gerhard Schröder.

Mīlenbahs, K. (1923-1932). Latviešu valodas vārdnīca [ME I-IV]. (J. Endzelīns, Ed.) (Vols. 1-4, Vol. 1-4). Rìga.

Rasiņš, A., \& Tauriņa, M. (1983). Pārskats par Latvijas PSR arheologiskajos izrakumos konstatētajām kultūraugu un nezāḷu sēklām. Arheoloǵija un etnogrāfija, 14, 171.

Sabaliauskas, A. (1990). Lietuviu kalbos leksika. Vilnius: Mokslas.

Schiller, K., \& Lübben, A. (1875-1880). Mittelniederdeutsches Wörterbuch [Schiller I-V] (Vol. 1-5). Bremen: Verlag von J. Kühtmann's Buchhandlung.

Schiller, K., \& Lübben, A. (1881). Mittelniederdeutsches Wörterbuch [Schiller VI] (Vol. 6). Bremen: Verlag von Hinricus Fischer.

Sehwers, J. (1953). Sprachlich-kulturhistorische Untersuchungen vornehmlich über den deutschen Einfluß im Lettischen. Berlin.

Smoczyński, W. (2007). Słownik etymologiczny języka litewskiego. Vilnius: Vilniaus universiteto leidykla.

Stender, G. F. (1789). Lettisches Lexikon: in zween Theilen abgefasset, und den Liebhabern der lettischen Litterature gewidmet von Gotthard Friedrich Stender: lettisches Wörter- und Namen-Lexikon. Erster Theil. Mitau: J. F. Steffenhagen.

Ulmann, C. C. (1872). Lettisches Wörterbuch. Erster Theil. Lettisch-deutsches Wörterbuch. Riga: Verlag von H. Brutzer \& Co.

Ulmann, C. C. (1880). Lettifches Wörterbuch von Ulmann und Brafche. Zweiter Theil. Deutfch-lettifches Wörterbuch. (G. Brafche, Ed.). Riga. 
Ilga Jansone On flora semantics in house names found in Vidzeme: materials contained in the $1826 \ldots$

Urbutis, V. (1981). Baltu etimologijos etiudai. Vilnius: Mokslas.

Wiedemann, F. J. (1973). Eesti-saksa sönaraamat. Tallinn: Valgus.

Winkler, E., \& Pajusalu, K. (Eds.). (2009). Salis-livisches Wörterbuch [Salis-Livischen]. Tallinn: Teaduste Akadeemia Kirjastus.

Гамкрелидзе, Т. В., \& Иванов, В. В. (1984). Индоевропейский язык и индоевропейцы (Vol. 1-2).

Тбилиси: Издательство Тбилисского университета.

Сталтмане, В. (1981). Латышская антропонимия: фамилии. Москва: Наука.

\section{Bibliography (transliteration)}

Balode, L. (2012). Liepa latviešu onomastiskajā kontekstā. In J. Kursīte (Ed.), Inkluzīvi (pp. 321355). Rīga: LU Akadēmiskais apgāds.

Balodis, P. (2008). Latviešu personvārdu etimoloǵiskās semantikas teorētiskais modelis un tā realizācija. Promocijas darbs. Rìga: Latvijas Universitāte.

Barons, K., \& Visendorfs, H. (1894-1915). Latvju dainas [BW] (Vol. 1-6). Jelgava-Pēterburga.

Būga, K. (1958-1961). Rinktiniai raštai [Būga RR III] (Vol. 1-3). Vilnius: Valstybinè politinès ir mokslinès literatūros leidykla.

Bušs, O. (2012). Dažas pārdomas par ozolu Latvijas toponīmiskajā panorāmā un géegrāfiskās nomenklatūras vārdu kontekstā. In Apvienotais Pasaules latviešu zinātnieku III kongress un Letonikas IV kongress „Zinätne, sabiedrība un nacionālā identitāte“. Valodniecības raksti (pp. 121-129). Rīga: LU Latviešu valodas institūts.

Endzelīns, J. (1961). Latvijas PSR vietvārdi [Lvv I] (Vol. 1(2)). Rīga: Latvijas PSR Zinātṇu akadēmijas izdevniecība.

Feldmann, H., \& Zur Muhlen, H., von (Eds.). (1990). Baltisches historisches Ortslexikon: II. Lettland [Ortslexikon]. Köln: Böhlau.

Fraenkel, E. (1955-1962). Litauisches etymologisches Wörterbuch [LEW] (Vol. 1-2). Heidelberg: Carl Winter Universitätsverlag.

Fürecker, C. (1997). Lettisches und Teutsches Wörterbuch zusahmen geschrieben und mit fleiß gesamlet von Christopher Fürecker [Fürecker I]. In T. G. Fennell, Fürecker's dictionary: the first manuscript. Rīga: Latvijas Akadēmiskā bibliotēka.

Gamkrelidze, T. V., \& Ivanov, V. V. (1984). Indoevropeřskiŭ iazyk i indoevroper̆tsy (Vol. 1-2). Tbilisi: Izdatel'stvo Tbilisskogo universiteta.

Graudonis, J. (1989). Nocietinātās apmetnes Daugavas lejtecēe. Rīga: Zinātne.

Graudonis, J., \& Apals, J. (Eds.). (2001). Latvijas senākā vēsture: 9. g.t. pr. Kr.--1200. g. [Latvijas senākā vēsture]. Rīga: Latvijas vēstures institūta apgāds.

Hirša, D. (1990). Koku, mežu un krūmu nosaukumi Sarkanmuižas (Ventas) vietvārdos. In Onomatica Lettica (pp. 102-148). Rīga: Zinātne.

Jansone, I. (2011). Pienenes (Taraxacum) nosaukumi. Humanitāro Zinātṇu Vēstnesis, (19), 35-50. 
Ilga Jansone On flora semantics in house names found in Vidzeme: materials contained in the 1826...

Kagaine, E. (1983). Érğemes izloksnes vārdnīca [ĒIV] (Vol. 3: P-Ž). Rīga: Zinātne.

Karulis, K. (1992). Latviešu etimolog̣ijas vārdnīca [LEV] (Vol. 1-2). Rīga: Avots.

Kettunen, L. (1938). Livisches Wörterbuch mit grammatischer Einleitung von Lauri Kettunen. Helsinki: Suomalais-ugrilainen seura.

Kregždys, R. (2012). Kopīgā baltu valodu leksika: flora Danguolè. In D. Mikulènienė \& A. Stafecka (Eds.), Baltu valodu atlants [Baltų kalbų atlasas; The Atlas of the Baltic Languages]. Vilnius: Lietuvių kalbos institutas.

Lange, J. (1773). Lettifch-Deutfcher Theil des volftändigen Lettifchen Lexici, darinnen nicht nur sämtliche Stammwörter diefer Sprache famt ihren Abftämlingen, fondern auch die feltene, nur in gewißen Gegenden gebräuchliche Wörter, zum Nach/chlagen, angezeigt werden. Schloß Ober//Pahlen.

Laumane, B., Bušmane, B., \& Stafecka, A. (Eds.). (1999). Latviešu valodas dialektu atlants: Leksika [LVDA]. Rịga: Zinātne.

Lietuvių kalbos žodynas [LKŽ I]. (1968) (Vol. I: A-B. Antras leidimas). Vilnius: Minties.

LVVA 199. fonds [foundation], 1. apraksts [description] (counting of souls in Vidzeme) [LVVA 199]. (n.d.).

Mancelius, G. (1638). Lettus, Das ift Wortbuch / Sampt angehegtem täglichem Gebrauch der Lettifchen Sprache; / Allen vnd jeden Außheimifchen / die in Churland / Semgallen vnd Lettifchem Liefflande bleiben / vnd fich redlich nehren wollen / zu Nutze verfertigt / Durch / GEORGIVM MANCELIVM Semgall. der H. Schrifft Licentiatum \&c. Erster Theil. Gedruckt vnnd verlegt zu Riga / durch Gerhard Schröder / Anno M. DC XXXVIII [Lettus].

Mancelius, G. (1638). Phraseologia Lettica: das ist: Täglicher Gebrauch der Lettischen Sprache. Diesem ist beygefüget das Spruchbuch Salomonis [Phras. Lettica]. Riga: Gerhard Schröder.

Mīlenbahs, K. (1923-1932). Latviešu valodas vārdnīca [ME I-IV]. (J. Endzelīns, Ed.) (Vols. 1-4, Vol. 1-4). Rìga.

Rasiņš, A., \& Tauriņa, M. (1983). Pārskats par Latvijas PSR arheologiskajos izrakumos konstatētajām kultūraugu un nezāḷu sēklām. Arheologiija un etnogrāfija, 14, 171.

Sabaliauskas, A. (1990). Lietuviu kalbos leksika. Vilnius: Mokslas.

Schiller, K., \& Lübben, A. (1875-1880). Mittelniederdeutsches Wörterbuch [Schiller I-V] (Vol. 1-5). Bremen: Verlag von J. Kühtmann's Buchhandlung.

Schiller, K., \& Lübben, A. (1881). Mittelniederdeutsches Wörterbuch [Schiller VI] (Vol.6). Bremen: Verlag von Hinricus Fischer.

Sehwers, J. (1953). Sprachlich-kulturhistorische Untersuchungen vornehmlich über den deutschen Einflu $\beta$ im Lettischen. Berlin.

Smoczyński, W. (2007). Słownik etymologiczny języka litewskiego. Vilnius: Vilniaus universiteto leidykla.

Staltmane, V. (1981). Latyshskaia antroponimiia: familii. Moskva: Nauka.

Stender, G. F. (1789). Lettisches Lexikon: in zween Theilen abgefasset, und den Liebhabern der lettischen Litterature gewidmet von Gotthard Friedrich Stender: lettisches Wörter- und Namen-Lexikon. Erster Theil. Mitau: J. F. Steffenhagen. 
Ulmann, C. C. (1872). Lettisches Wörterbuch. Erster Theil. Lettisch-deutsches Wörterbuch. Riga: Verlag von H. Brutzer \& Co.

Ulmann, C. C. (1880). Lettifches Wörterbuch von Ulmann und Brafche. Zweiter Theil. Deutfch-lettifches Wörterbuch. (G. Brafche, Ed.). Riga.

Urbutis, V. (1981). Baltu etimologijos etiudai. Vilnius: Mokslas.

Wiedemann, F. J. (1973). Eesti-saksa sönaraamat. Tallinn: Valgus.

Winkler, E., \& Pajusalu, K. (Eds.). (2009). Salis-livisches Wörterbuch [Salis-Livischen]. Tallinn: Teaduste Akadeemia Kirjastus.

\section{O semantyce roślinnej nazw domostw w Widzeme: materiały zawarte $\mathrm{w}$ spisie dusz $\mathrm{z}$ roku $1826 \mathrm{w}$ krainie Widzeme}

\section{Streszczenie}

Informacje o liczeniu dusz, obejmujące zarówno nazwy domostw, jak i nazwiska osób stanowią istotny aspekt onomastyki historycznej.

Pierwsze liczenie dusz w krainie historycznej Widzeme odbyło się w 1782 r. i zbiegło się w czasie z podobnym, czwartym spisem, przeprowadzonym w guberniach rosyjskich. Kolejne spisy odbywały się nieregularnie: piąty w 1795 r., szósty w 1811, siódmy w 1816, ósmy w 1834, dziewiąty w 1850, i ostatni, dziesiąty, w roku 1858.

Liczba nazw domostw uwzględnionych w spisie dusz z 1826 r. w Widzeme wynosi 14 500, łącznie z domami chłopskimi, będącymi odrębnymi częściami innych posiadłości, choć noszącymi tę samą co one nazwę. Nazwy domów pochodzące od nazw roślin (łącznie z nazwami grzybów) podano w przypadku 574 miejsc zamieszkania, co stanowi tylko ok. 4\% ogółu nazw, zakładając, że powtarzające się nazwy liczono osobno. Ponieważ w przypadku niektórych siedzib brak danych (zaginęły) w spisie $z$ roku 1826, informacje o nich zaczerpnięto ze spisów poprzednich i następnych.

Nazwy siedzib zamieszczone w spisie dusz z 1826 r. opierają się w szerokim zakresie na semantyce roślinnej, przy czym wyraźnie uprzywilejowane są jednostki leksykalne kojarzone z nazwami drzew. Najprawdopodobniej jest to związane z elementami krajobrazu, znajdującymi się w bezpośrednim sąsiedztwie poszczególnych domostw, ale może też być świadectwem stosunku ich mieszkańców do otaczającej przyrody oraz do swojej pracy. Aby móc wyciągnąć dalsze wnioski na temat obecności semantyki roślinnej w nazewnictwie domostw, konieczne jest przebadanie wszystkich zapisów historycznych aż po czasy nam współczesne.

Słowa kluczowe: onomastyka; nazewnictwo domostw; spisy dusz w XIX w.; flora; semantyka 


\section{Summary}

The information of the counting of souls containing both house names and names of individuals is an essential aspect of historical onomastics.

The first counting of souls in Vidzeme took place in 1782 and coincided with the $4^{\text {th }}$ analogous census of the provinces of Russia. Subsequently these took place at irregular intervals, the $5^{\text {th }}$ in 1795 , the $6^{\text {th }}$ in 1811 , the $7^{\text {th }}$ in 1816 , the $8^{\text {th }}$ in 1834 , the $9^{\text {th }}$ in 1850 , and the final, $10^{\text {th }}$ in 1858 .

The number of house names entered in the 1826 counting of souls in Vidzeme province (guberna) is 14,500 , including those of peasant homes that had been separated from another property whilst retaining the same name. House names based on flora (incl. names of mushrooms) semantics are listed for 574 dwellings, which represent just about $4 \%$ of all house names listed for Vidzeme, providing that repeated house names are counted separately. In case of several manors data is missing (lost) for the 1826 census, information for these manors is taken from previous and subsequent censuses.

In many instances (279 cases registered) house names were based on the names of deciduous trees found in their immediate vicinity: such names comprise $48.6 \%$ of all house names of flora semantic origin, i. e., ozols 'oak-tree', bèrzs 'birch-tree', kārkls 'osier', liepa 'linden tree', klava 'maple tree', apses 'aspen', osis 'ash tree', alksnis 'alder', lazda 'hazel-tree', vittols 'willow', ieva 'bird cherry'.

Names based on names of conifers are found (35 instances were recorded, or 6.1\% of all house names based on flora semantics), i. e., egle 'spruce tree', paeglis, kadikis 'juniper', priede 'pine-tree'.

House names based on names of fruit trees and bushes are only occasionally found in Vidzeme, with 8 recorded instances, or 1.4\% of all house names based on flora semantics, i. e., äbele 'apple tree', and upene 'black-currant'.

The next sub-group of house names based on flora semantics comprises those based on names of cereals. This is one of the most widely occurring flora semantics sub-groups and contains 58 entries, or $10,1 \%$ of all house names based on flora semantics, i. e., auzas 'oats', rudzi 'rye', mieži 'barley', kvieši 'wheat', griki 'buckwheat'.

House names have been found based on terms of 6 legumes, which represents $1 \%$ of all house names based on flora semantics, i. e., zirnis 'pea', pupa, 'bean'.

Names of common vegetables are the basis for a considerable number of house names. i. e. 53 instances are recorded, representing 9.2\% of all house names derived from flora semantics, i. e., rutks, ruduks 'radish', kāposts 'cabbage', rācenis 'turnip', sīpols 'onion', ķiploks 'garlic', kālis 'swede', gurķis 'cucumber'.

House names also derive from terms of widely-cultivated plants such as kanepes 'hemp', apini 'hops' and lini 'flax'. These have been the basis for 40 house names, which represent $7 \%$ of all hose names based on flora semantics. 
House names are also based on the names of cultivated and wild herbal plants, and of garden weeds. 47 such cases have been recorded, corresponding to $8.2 \%$ of all house names based on flora semantics, i. e., dadzis 'thistle', āboliņš 'clover', and amoliņ̌ 'sweet clover', dille 'dill', grislis 'sedge', smilga 'bent grass', usne 'creeping thistle', pienene 'dandelion', pērkones 'charlocks', niedre 'reed', skosta 'horse-tail', vībotne 'mugwart'.

A total of 32 house names based on three flower terms, roze 'rose', magone 'poppy' and astere 'aster' have been recorded; this represents $5.6 \%$ of all house names based on flora semantics. The majority (26) of these house names are based on terms of roses.

A number of house names in Vidzeme appear to be based on names of mushrooms. 6 such names have been recorded, which represent $1 \%$ of all house names based on flora semantics, i. e., bekas 'boletus', krimilde, and rudmiese 'Loctarius'.

House names listed in the 1826 counting of souls are based on a wide range of flora semantics, with a clear preference for lexemes associated with names of trees. It is possible that this reflects landscape elements close to these homes, as well as the place that these features have in the relationship of home owners with nature, and their work. In order to draw any deeper conclusions about the presence of flora semantics in house names it would be necessary to examine all relevant historical records up to the present time.

Keywords: onomastics; house names; counting of souls in $19^{\text {th }}$ century; flora semantic 